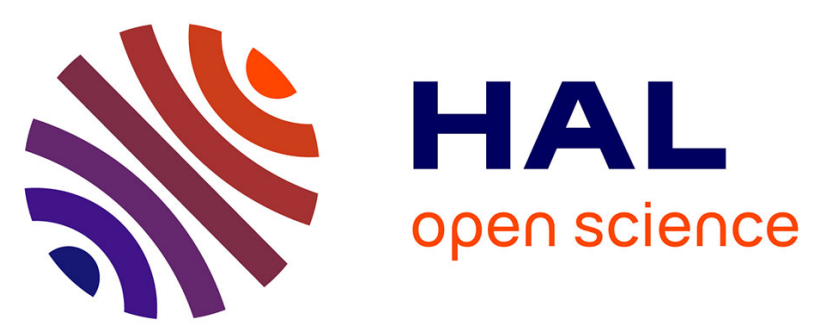

\title{
Examining suspended sediment sources and dynamics during flood events in a drained catchment using radiogenic strontium isotope ratios $(87 \mathrm{Sr} / 86 \mathrm{Sr})$
}

Marion Le Gall, O. Evrard, François Thil, Anthony Foucher, J. Patrick

Laceby, Louis Manière, Sébastien Salvador-Blanes, Sophie Ayrault

\section{To cite this version:}

Marion Le Gall, O. Evrard, François Thil, Anthony Foucher, J. Patrick Laceby, et al.. Examining suspended sediment sources and dynamics during flood events in a drained catchment using radiogenic strontium isotope ratios (87Sr/86Sr). Chemical Geology, 2017, 449, pp.147 - 157. 10.1016/j.chemgeo.2016.12.007 . hal-01584172

\author{
HAL Id: hal-01584172 \\ https://hal.science/hal-01584172
}

Submitted on 14 May 2020

HAL is a multi-disciplinary open access archive for the deposit and dissemination of scientific research documents, whether they are published or not. The documents may come from teaching and research institutions in France or abroad, or from public or private research centers.
L'archive ouverte pluridisciplinaire HAL, est destinée au dépôt et à la diffusion de documents scientifiques de niveau recherche, publiés ou non, émanant des établissements d'enseignement et de recherche français ou étrangers, des laboratoires publics ou privés. 
1 Examining suspended sediment sources and dynamics during flood events in a drained catchment 2 using radiogenic strontium isotope ratios $\left({ }^{87} \mathrm{Sr} /{ }^{86} \mathrm{Sr}\right)$

3 Marion Le Gall ${ }^{a^{*}}$, Olivier Evrard ${ }^{a}$, François Thil ${ }^{a}$, Anthony Foucher ${ }^{b}$, J. Patrick Laceby ${ }^{a}$, Louis Manière , 4 Sébastien Salvador-Blanes ${ }^{b}$, Sophie Ayrault ${ }^{a}$

5 a Laboratoire des Sciences et de l'Environnement, LSCE/IPSL, CEA-CNRS-UVSQ, Université Paris-Saclay, F- 91198 Gif-sur6 Yvette, France

$7{ }^{b}$ E.A 6293, Laboratoire GéoHydrosystèmes Continentaux (GéHCO), Université F. Rabelais de Tours, Faculté des Sciences 8 et Techniques, Parc de Grandmont, 37200 Tours, France

Highlights

- Soil samples were discriminated according to catchment substrate (i.e. carbonate and silicate)

- ${ }^{87} \mathrm{Sr} /{ }^{86} \mathrm{Sr}$ ratios of suspended sediment varied depending on hydrological conditions

- Different particle size fractions were modelled for different flood intensities (i.e. $<2 \mathrm{~mm}$ and $<2 \mu \mathrm{m}$ )

- Carbonate source soils dominated two less intense flood events $(63 \%)$ whereas silicate source soils dominated a higher intensity flood (72\%)

- Field drainage systems likely enhance the hillslope to river connectivity, particularly for the finest particles

Abstract

Soil erosion is recognized as one of the main processes of land degradation in agricultural areas. High suspended sediment loads, often generated from eroding agricultural landscapes, are known to degrade downstream environments. Accordingly, there is a need to identify suspended sediment sources and to investigate their dynamics. Here, soil and sediment strontium isotopic ratios were used to examine suspended sediment sources and dynamics in a lowland drained catchment in France.

Suspended sediment $(n=14)$ was collected in stream and at tile drain $(n=4)$ outlets during three flood events between December 2013 and February 2014. Potential source soils $(n=28)$ representative of the carbonate and silicate substrates found in the catchment were sampled and analyzed. Strontium isotopic ratios $\left({ }^{87} \mathrm{Sr} /{ }^{86} \mathrm{Sr}\right)$ were measured in different particle size fractions $(<2 \mu \mathrm{m},<63 \mu \mathrm{m}$ and $<2 \mathrm{~mm})$.

Soil ${ }^{87} \mathrm{Sr} /{ }^{86} \mathrm{Sr}$ ratios significantly discriminated between source samples classified as carbonate $(0.712625$ to $0.717815)$ and silicate $(0.719287$ to 0.724631$)$ soils. ${ }^{87} \mathrm{Sr} /{ }^{86} \mathrm{Sr}$ ratios measured in suspended sediment $(0.713660$ to 0.720571$)$ reflect variations in source contributions during different hydrological conditions. The ${ }^{87} \mathrm{Sr} /{ }^{86} \mathrm{Sr}$ ratios varied in the different fractions of soil samples (i.e. $<2 \mu \mathrm{m},<63 \mu \mathrm{m}$ and $<2 \mathrm{~mm}$ ) and in suspended sediment samples. Suspended sediment was interpreted as a mixture of two end-members, with the dominant contribution of the $<2 \mu \mathrm{m}$ fraction of soil samples occurring during small scale flood events and the $<2 \mathrm{~mm}$ fraction during more intense flood events. Modelling results indicate that carbonate source soil contributions are variable, with their highest contributions occurring during the two first flood events compared to the last flood event.

The results also show that the tile drainage system enhances the connectivity between cultivated hillslopes and the river network, providing a preferential pathway for fine $(<2 \mu \mathrm{m})$ particles. This study demonstrates the potential of using strontium isotopic ratios to examine the variations of suspended sediment sources in drained catchments with contrasting carbonate and silicate sources. More importantly, the results highlight 
41 the need to improve the management of sediment exported from tile drains in similar agricultural 42 environments, as they were demonstrated to transfer very fine material to the riverine environment.

43 Keywords: ${ }^{87} \mathrm{Sr} /{ }^{86} \mathrm{Sr}$ ratio, suspended sediment, soil erosion, sediment tracing 44 


\section{Introduction}

Accelerated soil erosion often results in elevated sediment loads (Owens et al., 2005). High sediment loads may lead to the siltation of river channels and reservoirs (Verstraeten and Poesen, 1999; Walling and Fang, 2003; Gay et al., 2014). These problems are exacerbated for the clay to loam fractions of sediment (typically $<63 \mu \mathrm{m}$ ) that are transported the farthest from their sources. Importantly, fine sediment may also transport various contaminants, such as metals (Priadi et al., 2011), polycyclic aromatic hydrocarbons (Gateuille et al., 2014), nutrients (Beusen et al., 2005) and fallout radionuclides (Chartin et al., 2013).

There is a need to improve our understanding of sediment source dynamics in order to design effective sediment management programs. This is important for cultivated catchments of Northwestern Europe (Russell et al., 2001; Walling et al., 2002) where the intensification of agriculture after World War II resulted in an increase of sediment yields (Vanmaercke et al., 2015). In particular, knowledge of erosion processes and sediment sources is limited for catchments where tile drains were installed after the 1950s (Sogon et al., 1999; King et al., 2014). Drainage networks were installed in many agricultural catchments worldwide and although several studies suggest that the drainage system may increase the connectivity between cultivated hillslopes and the river network (Walling and Collins, 2008; Foucher et al., 2015), additional information is needed to characterize the source and nature of eroded material transported in these systems.

Eroded material is transported in rivers as suspended load or bedload, and rivers transport eroded material as both dissolved and particulate load. River monitoring is important for understanding sediment transport processes (Horowitz, 2008; Smith and Dragovich, 2009; Liu et al., 2011; Gourdin et al., 2014) or to estimate chemical mass budgets (e.g. Viers et al., 2009). In many cases, sediment fluxes and their associated contaminants are controlled by the occurrence of large flood events as demonstrated by numerous catchment-scale studies in which long time records are available (Audry et al., 2004; Coynel et al., 2007; Ollivier et al., 2011). Nevertheless, small agricultural catchments with extensive drainage networks, where significant suspended sediment export occurs during small and medium sized flood events, have received limited attention. Accordingly, investigating sediment sources in small drained agricultural catchments may provide insight into fundamental hydrological and erosion processes.

Sediment provenance can be determined by analyzing the sediment geochemistry of river material that is essentially a mixture between its lithological and pedological sources (Collins et al., 2010; Evrard et al., 2011). In addition to the analysis of major and trace elements, targeted isotopic ratios are a powerful tool to discriminate the contributions of potential sediment sources. This ability was demonstrated for strontium isotopes $\left({ }^{87} \mathrm{Sr}\right.$ and ${ }^{86} \mathrm{Sr}$ ) that are not fractionated during weathering processes (dissolution of primary minerals and precipitation of secondary phases). Although the bedrock ${ }^{87} \mathrm{Sr} /{ }^{86} \mathrm{Sr}$ ratio depends on the $\mathrm{Rb} / \mathrm{Sr}$ ratio of the constitutive minerals and age (Faure, 1986; Albarède, 1995), the minerals neoformed during their transformation in soils should maintain their bedrock strontium isotopic signatures (Graustein, 1989; Douglas et al., 1995).

As a consequence, ${ }^{87} \mathrm{Sr}$ and ${ }^{86} \mathrm{Sr}$ isotopes have been extensively used to investigate weathering and erosion processes (Négrel et al., 1993; Gaillardet et al., 1997; Probst et al., 2000; Semhi et al., 2000; PiersonWickmann et al., 2009; Brennan et al., 2014) and for tracing river water masses (Eikenberg et al., 2001; Brenot et al., 2008; Bouchez et al., 2011a). Few studies have reported variations of ${ }^{87} \mathrm{Sr} /{ }^{86} \mathrm{Sr}$ ratios during floods in large rivers in both dissolved (Négrel et al., 1993; Grosbois et al., 1999; Roy et al., 1999; Négrel and Petelet-Giraud, 2004; Petelet-Giraud and Négrel, 2007) and particulate loads (Douglas et al., 1995; Allègre et al., 1996; Asahara et al., 1999). These latter studies demonstrated the potential of ${ }^{87} \mathrm{Sr} /{ }^{86} \mathrm{Sr}$ ratios to 
discriminate sediment sources in riverine environments in general, and to discriminate between carbonate and silicate sources or between shield and volcanic terranes in particular.

The objective of this study is to investigate the sources of suspended sediment and to quantify their dynamics in the Louroux catchment (France), a small agricultural catchment representative of lowland drained areas of Northwestern Europe. In this catchment, the installation of dense drainage systems were shown to increase the connectivity between eroded soils and the river network, with the preferential transfer through the drains of very fine particles originating from the soil surface to the river network (Foucher et al., 2014).

To improve our understanding of suspended sediment sources in this drained and intensively cultivated catchment, ${ }^{87} \mathrm{Sr} /{ }^{86} \mathrm{Sr}$ and chemical element ratios were measured in suspended sediment during three flood events and three particle size fractions in potential source soil samples (i.e. $<2 \mathrm{~mm},<63 \mu \mathrm{m}$ and $<2 \mu \mathrm{m}$ fractions). The objective of these measurements is to identify the sources supplying sediment to the river network and to examine their potential variations during a sequence of flood events. Accordingly, geochemical variations were examined according to hydrological conditions, suspended sediment endmembers were identified, and the respective contribution of each end-member was estimated for each flood event.

\section{Material and methods}

\subsection{Study site}

The Louroux catchment $\left(24 \mathrm{~km}^{2}\right)$ is a small agricultural catchment located in the central part of the Loire river basin, France (Fig. 1A). It is characterized by a relatively flat topography (mean slope of $0.4 \%$; elevation ranging between 99 and $127 \mathrm{~m}$ ). The climate is temperate oceanic, with a mean annual rainfall of $684 \mathrm{~mm}$ (between 1971 and 2000) (Météo France). Cropland (intensive cereal production) is the main land use (78\%) followed by grassland (18\%) and woodland (4\%) (European Environment Agency, 2002). Organic and mineral fertilizers are commonly used in the catchment. The geology exclusively consists of continental and marine sedimentary rocks. Six different lithologies are found in this lowland catchment (Fig. 1B) although they crop out at very limited locations. Senonian flint clays (23\%) constitute the oldest and deepest formation. Tertiary detrital formations, as Eocene silicic conglomerate (2\%), are found in the middle of the basin. Ludian Touraine lacustrine limestone $(6 \%)$ is found in the western part of the catchment where it is covered with Helvetian shelly sands (18\%). Post-Helvetian sand and continental gravel (32\%) cover the largest area and result from fluviatile spreading. Quaternary loess $(18 \%)$ covers tertiary deposits in the upstream part of the catchment (Rasplus et al., 1982). These lithologies were regrouped in two classes: a carbonate area composed of Touraine lacustrine limestone, Helvetian shelly sand and Post-Helvetian sand and continental gravel, and a silicate area comprising the remaining lithologies (Fig. 1C). Importantly, the carbonate substrates were predominately located in the southern part of the catchment. According to the Food and Agriculture Organization classification (World Reference Base for Soil Resources, 2006), most of the soils are hydromorphic soils classified as Neoluvisols and prone to surface crusting except in the southern part of the catchment where Calcosols and Calcisols overlie the Touraine lacustrine limestone. 

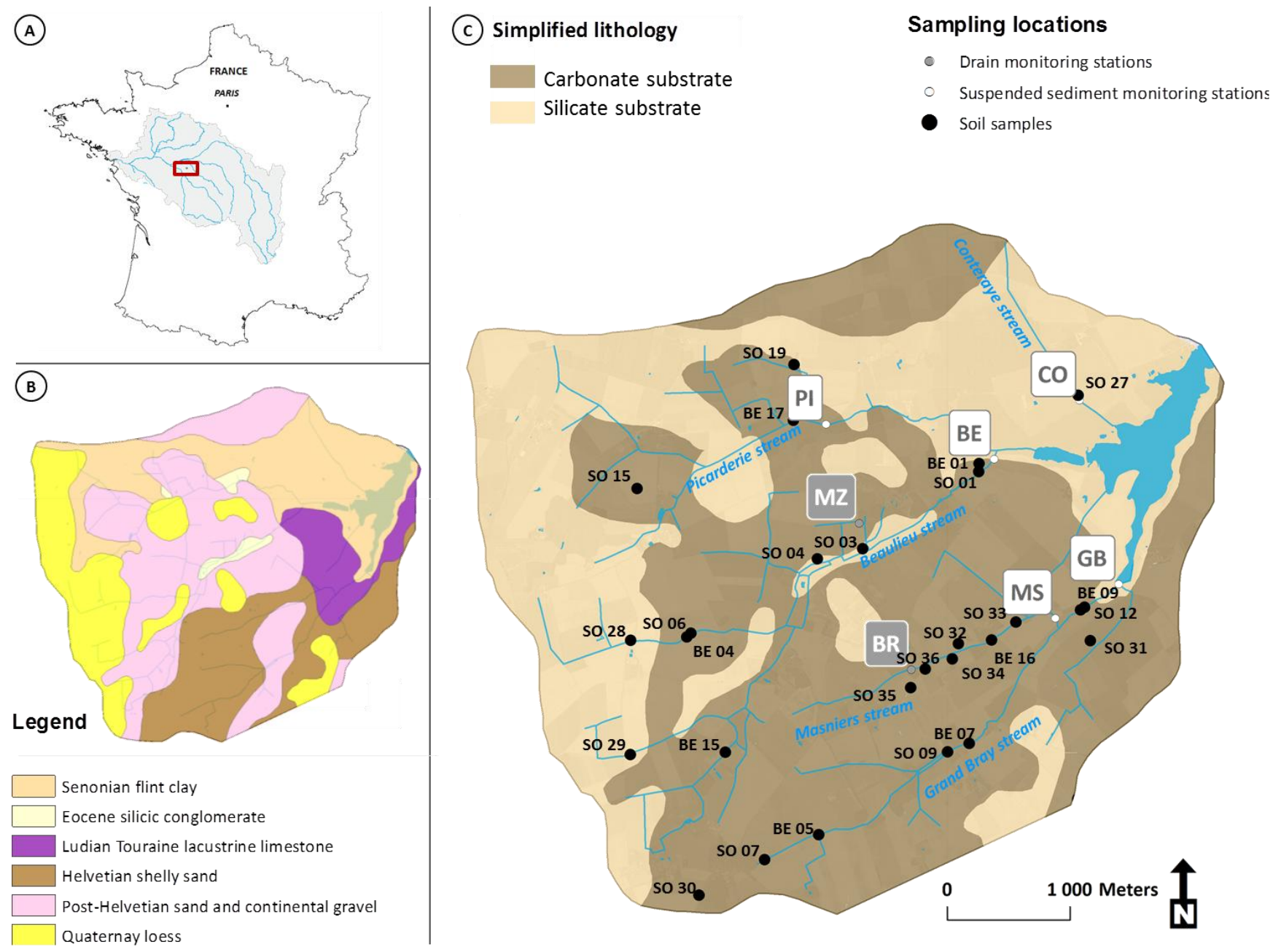

Figure 1. Map of the Louroux catchment in the Loire River basin (France) (A) along with the lithological map of the area (B) and the locations of soil sampling, river monitoring stations equipped with automatic samplers (in white) and tile drain outlet monitoring stations (in grey) (CO: Conteraye, BE: Beaulieu, PI: Picarderie, GB: Grand Bray, MS: Masniers, MZ: Mazère, BR: Brépinière) (C). For the soil samples, SO refers to surface samples and BE refers to channel bank samples.

Large-scale modifications of land use and agricultural practices took place in the Louroux catchment over the last 70 years. A succession of land consolidation schemes was implemented in the area, which modified the river network and installed a dense tile drain system to evacuate stagnating water. More than 220 tile drain outlets were installed throughout the catchment to drain the soils. These modifications led to increased sediment yields (maximal value of $1100 \mathrm{t} \mathrm{km}^{-2} \mathrm{yr}^{-1}$ during the 1960-1980 period) in the Louroux Pond (0.5 $\mathrm{km}^{2}$ ), located at the catchment outlet (Foucher et al., 2014). Five main streams drain to the Louroux Pond: the Conteraye, Picarderie, Beaulieu, Masniers and Grand Braye streams. The main flow direction is from the western to the eastern part of the catchment, where the pond is located (Fig. 1C).

Soil and channel bank samples (respectively referred to as SO and BE in Fig. 1C) were collected between January 2013 and April 2014 in cropland areas. Surface sources $(n=20)$ were sampled by scraping the top 2-3

\subsection{Sampling} $\mathrm{cm}$ layer of soil. Channel bank sources $(\mathrm{n}=8)$ were sampled by scraping a 2-3 $\mathrm{cm}$ layer of the sidewall from eroding channel banks. A plastic spatula was used to collect these samples to avoid potential contamination. 
Source samples were composed of three to five sub-samples, all collected within a radius of $10 \mathrm{~m}$. During sampling, care was taken to cover soils corresponding to the range of substrates found in the catchment.

\subsubsection{Suspended sediment collection}

Five monitoring stations ( $\mathrm{CO}, \mathrm{PI}, \mathrm{BE}, \mathrm{MS}$, GB stations in Fig. $1 \mathrm{C}$ ) equipped with automatic samplers containing twenty-four $1 \mathrm{~L}$ polypropylene bottles were installed on five streams draining to the Louroux Pond. For each monitoring site and each flood, one acid-cleaned $1 \mathrm{~L}$ polypropylene bottle was dedicated for geochemical analyses. In addition to the river monitoring sites, two stations were installed at tile drain outlets to characterize the properties of the sediment transiting through the drainage system. Suspended sediment exported from drains (BR, MZ stations) was collected in the same way as suspended sediment in the rivers. Water level and turbidity were continuously recorded at the seven monitoring stations to estimate water discharge and suspended sediment concentrations. For the flood events investigated, data were available for four of the monitoring stations (BR, GB, MS for the three floods and BE for the two first floods). Three flood events were investigated (December 30, 2013, January 29, 2014 and February 13, 2014). Eighteen samples of river water were collected for geochemical analyses, including fourteen in the river monitoring stations and four at tile drain outlets. For each flood, one sample of river water was collected at the beginning of the recession stage of the hydrograph. During the two first floods, samples were collected at every station (5 river and 2 tile drain samples) for each event. During the last flood, samples were only collected at 4 river monitoring stations (excluding the $\mathrm{CO}$ and $\mathrm{BR}$ and $\mathrm{MZ}$ tile drain stations).

\subsection{Sample processing and analysis}

\subsubsection{Sample preparation}

In the laboratory, soil samples were dried at $40^{\circ} \mathrm{C}$ and sieved to $2 \mathrm{~mm}$ before analysis. The $<63 \mu \mathrm{m}$ and $<2 \mu \mathrm{m}$ particle sizes were fractionated for a selection of soil samples $(n=8)$. Sieving sediment source material to $<63 \mu \mathrm{m}$ facilitates the direct comparison of its properties with those of suspended sediment, as it is widely accepted that fine material (typically $<63 \mu \mathrm{m}$ ) is preferentially transported in suspension (Koiter et al., 2013; Smith and Blake, 2014). Furthermore, the $<2 \mu \mathrm{m}$ fraction containing the clay minerals was separated. The $<63$ $\mu \mathrm{m}$ fraction was isolated by dry sieving and settling columns were used to isolate the $<2 \mu \mathrm{m}$ fraction by sedimentation using deionized water. The larger particles (i.e $>2 \mu \mathrm{m}$ ) were expected to have settled after a given period calculated using Stokes' law. A fall distance of $3 \mathrm{~cm}$ was calculated for the $<2 \mu \mathrm{m}$ fraction on the basis of a constant temperature of $20^{\circ} \mathrm{C}$ and a density of $2.65 \mathrm{~g} \mathrm{~cm}^{-3}$. After 140 minutes, the supernatant solution with particles $<2 \mu \mathrm{m}$ was removed and dried at $40^{\circ} \mathrm{C}$. Suspended sediment concentrations were determined by the filtration of a known volume of water $(120 \mathrm{~mL}$ to $900 \mathrm{~mL})$ through dried, acid-cleaned and pre-weighted glass fiber filters (Whatman, GF/F, $47 \mathrm{~mm} \varnothing, 0.7 \mu \mathrm{m}$ pore size). Suspended sediment quantities collected on the filters ranged from 59 to $347 \mathrm{mg}$ (weighing error: $<3 \%$ ).

\subsubsection{Geochemical measurements}

\section{Bulk mineralization}

Approximately $100 \mathrm{mg}$ of soil and channel bank material were dissolved with $3 \mathrm{~mL} \mathrm{HF} \mathrm{(47-51 \% )} \mathrm{and} 3 \mathrm{~mL}$ $\mathrm{HClO}_{4}(65-71 \%)$ in closed Teflon vessels under pressure on hot-plates at $150^{\circ} \mathrm{C}$ for 240 min (Digiprep, SCP Science protocol). After cooling, solutions were evaporated to dryness. Samples were then digested using aqua regia: $3.75 \mathrm{~mL} \mathrm{HCl}(34-37 \%)$ and $1.25 \mathrm{~mL} \mathrm{HNO}$ (67\%) at $110^{\circ} \mathrm{C}$ for $120 \mathrm{~min}$ (Digiprep SCP Science 
protocol). Solutions were then evaporated to dryness. Finally, samples were dissolved and evaporated successively three times in $1 \mathrm{~mL}$ of $\mathrm{HNO}_{3}(67 \%)$ and diluted in $50 \mathrm{~mL}$ of ultrapure water (Milli-Q). Ultrapure reagents were used (Normatom grade, VWR, France for $\mathrm{HNO}_{3}$, and "Trace Metal Grade", Fisher Chemical, France for $\mathrm{HF}, \mathrm{HClO}_{4}$ and $\mathrm{HCl}$ ) and for each set of total digestion, a reference material (IAEA lake sediment SL1) and a chemical blank were digested in the same way to control chemical mineralization efficiency.

Prior to digestion, dried, weighted suspended sediment filters were cut into two parts using ceramic scissors. Half of each filter (between 50 and $110 \mathrm{mg}$ ) was digested in closed Teflon vessels using the same procedure as described above. For each batch of total digestions, a clean filter was digested in the same way as the samples to check for any potential contamination.

\section{Determination of major and trace element concentrations}

Major and trace element concentrations ( $\mathrm{Na}, \mathrm{Mg}, \mathrm{K}, \mathrm{Ca}, \mathrm{Al}, \mathrm{Rb}$, and $\mathrm{Sr}$ ) were determined in digested solutions using an inductively coupled plasma quadrupolar mass spectrometer (ICP-QMS) (X-Series, CCT $\mathrm{II}^{+}$ Thermoelectron, France). Internal standards (Re, Rh and In; SPEX, SCP Science, France) were used to correct for instrumental drift and plasma fluctuation. To limit interference, analysis was performed using a collision cell technology (CCT) which introduces a supplementary gas mixture of $\mathrm{H}_{2}(7 \%)$ and $\mathrm{He}(93 \%)$ for the determination of $\mathrm{Rb}$ and $\mathrm{Sr}$ concentrations.

A certified river water sample (SRM 1640a, NIST, Gaithersburg, USA) was used to control the ICP-QMS calibration. The overall quality of the digestion procedure and of ICP-QMS measurements was controlled by analyzing a certified lake sediment material (SL-1, International Atomic Energy Agency, Vienna). These standards were analyzed routinely (every 15-25 samples). Good agreement was observed between the data obtained and the certified values ( $\mathrm{n}=91$ for SL-1 measurements). In the particulate compartment, analytical uncertainties did not exceed $10 \%$ (except for $\mathrm{Ca}$, with a maximal analytical error of $13 \%$ ). In the blank filter, major and trace element concentrations did not exceed $2 \%$ of the concentrations measured in suspended sediment, except for Na measurements which had a maximum contribution of $8 \%$.

\section{Sr purification and isotopic measurements}

Chemical separation of $\mathrm{Sr}$ from $\mathrm{Rb}$ and $\mathrm{Ca}$ was performed using a cation-exchange procedure. A Sr specific resin was used (Sr-SPEC resin, Eichrom) and packed on lab-made polyethylene microcolumns (700 $\mu \mathrm{L}$ resin). After the bulk digestion, a calculated volume of each sample, equivalent to $200 \mathrm{ng}$ of $\mathrm{Sr}$ in $4 \mathrm{~mL} \mathrm{HNO} 3 \mathrm{~N}$, was prepared. The resin was conditioned three times with $25 \mathrm{~mL}$ of $\mathrm{HCl} 1 \mathrm{~N}$ and $25 \mathrm{~mL}$ of HCl $3 \mathrm{~N}$ to remove potential traces of $\mathrm{Sr}$ and $\mathrm{Pb}$, and then rinsed with ultrapure water (Milli-Q) until pH 6-7 was reached. The resin was then loaded onto pre-cleaned extraction chromatographic microcolumns and rinsed successively with $2 \mathrm{~mL}$ of $\mathrm{HNO}_{3} 3 \mathrm{~N}, 2 \mathrm{~mL}$ of ultrapure water (Milli-Q) and $1 \mathrm{~mL}$ of $\mathrm{HNO}_{3} 3 \mathrm{~N}$. Digestion solutions (containing $200 \mathrm{ng}$ of $\mathrm{Sr}$ ) were then loaded onto columns. Sr elution was realized using $3 \mathrm{~mL}$ of $\mathrm{HNO}_{3} 3 \mathrm{~N}$ and $2.5 \mathrm{~mL}$ of ultrapure water (Milli-Q). Sr recovery (measured to $85 \%, \sigma=11.5 \%, n=129$ ) and efficiency of purification were determined by comparing the $\mathrm{Sr}$ and $\mathrm{Ca}$ concentrations in the original digest (after the bulk digestion) and in the eluted Sr fraction. More than $90 \%$ of the Ca was eliminated after the chemical extraction.

Sr isotope ratio analyses were carried out using a Thermo Finnigan Neptune-Plus Multi-collector Inductively Coupled Plasma Mass Spectrometry (MC-ICP-MS) instrument at the Laboratoire des Science du Climat et de I'Environnement. The purified $\mathrm{Sr}$ fractions obtained after chemical separation were diluted with $0.5 \mathrm{~N} \mathrm{HNO}_{3}$, adjusting the $\mathrm{Sr}$ concentration to $20 \mu \mathrm{g} / \mathrm{L}$. Reproducibility of the ${ }^{87} \mathrm{Sr} /{ }^{86} \mathrm{Sr}$ ratio measurements was controlled with replicate analyses of the NBS 987 standard, the mean value obtained was $0.710304 \pm 11 \times 10^{-6}(2 \sigma, n=88)$. Ratios obtained were normalized to the NBS 987 standard value of 0.710245 and ${ }^{86} \mathrm{Sr} /{ }^{88} \mathrm{Sr}=0.1194$ was 
adopted to calibrate mass bias during the $\mathrm{Sr}$ isotope measurements. Two other standards were also used, the JCt-1 (carbonate mineral, accepted value of 0.709150 ) and the Durango apatite (accepted value of 0.706327 ). Recalculated mean values, normalized to the NBS 987, obtained were respectively $0.709267 \pm 11 \times 10^{-6}(2 \sigma$, $\mathrm{n}=18)$ and $0.706346 \pm 13 \times 10^{-6}(2 \sigma, \mathrm{n}=24)$.

\subsection{Source discrimination analyses and modelling}

Suspended sediment samples were hypothesized to derive from two source end-members reflecting the mixing of particles originating from source soils developed on carbonate and silicate substrates. To facilitate the presentation or results and discussion, these endmembers will be further referred to "carbonate soils" and "silicate soils".

Non-parametric tests were used to determine whether isotope ratios were significantly different in suspended sediment and in soil samples (Collins et al., 1997; Laceby et al., 2015). The non-parametric MannWhitney $U$-test was used to examine differences and similarities between suspended sediment sources and suspended sediment samples at a significance level of $p<0.05$.

To quantify the relative contribution of the sources (i.e., carbonate soils vs silicate soils) to suspended sediment samples, ${ }^{87} \mathrm{Sr} /{ }^{86} \mathrm{Sr}$ ratios and $\mathrm{Sr}$ concentrations were incorporated in the following equation (Eq. 1):

$$
R_{S S}=\frac{x_{c} \cdot C_{c} \cdot R_{c}+x_{s} \cdot C_{s} \cdot R_{S}}{x_{c} \cdot C_{c}+x_{S} \cdot C_{S}}
$$

where $R_{S S}, R_{C}, R_{S}$ are the respective ${ }^{87} S r /{ }^{86} S r$ ratios in suspended sediment, carbonate and silicate soil samples; $\mathrm{C}_{\mathrm{C}}$ and $\mathrm{C}_{\mathrm{S}}$ are the respective $\mathrm{Sr}$ concentrations in carbonate and silicate soil samples; and $x_{\mathrm{C}}$ and $x_{\mathrm{S}}$ (with $x_{\mathrm{C}}+x_{\mathrm{S}}$ $=1$ ) are the respective carbonate and silicate contributions to suspended sediment.

Carbonate and silicate soil contributions to suspended sediment were estimated by minimizing the difference between the ${ }^{87} \mathrm{Sr} /{ }^{86} \mathrm{Sr}$ ratio measured in each suspended sediment sample by MC-ICP-MS and the ${ }^{87} \mathrm{Sr} /{ }^{86} \mathrm{Sr}$ ratio $\left(R_{s S}\right)$ calculate following (Eq. 1$)$.

For the two first flood events, ${ }^{87} \mathrm{Sr} /{ }^{86} \mathrm{Sr}$ ratios and $\mathrm{Sr}$ concentrations measured in the $<2 \mu \mathrm{m}$ fraction were incorporated in the mixing equation while for the third flood event, measurements in the $<2 \mathrm{~mm}$ fraction were used. Both end-members were characterized by the mean value of the ${ }^{87} \mathrm{Sr} /{ }^{86} \mathrm{Sr}$ ratios and $\mathrm{Sr}$ concentrations measured in the carbonate and silicate soils.

\section{Results}

\subsection{Spatial variations of ${ }^{87} \mathrm{Sr} /{ }^{86} \mathrm{Sr}$ ratios in source samples}

A range of ${ }^{87} \mathrm{Sr} /{ }^{86} \mathrm{Sr}$ ratios was observed in source samples collected within the Louroux catchment. The ${ }^{87} \mathrm{Sr} /{ }^{86} \mathrm{Sr}$ ratios varied between 0.712625 and 0.722685 in channel bank samples $(\mathrm{n}=8)$, and between 0.712763 and 0.724631 in soil samples $(n=20)$ (Fig. 2, Supplementary Table S1). A Mann-Whitney $U$ test reported the absence of significant differences between these two sources (MW $p=0.355$ ). Accordingly, channel bank and soil samples were not considered as distinct sources. 
Channel bank samples

Soil samples

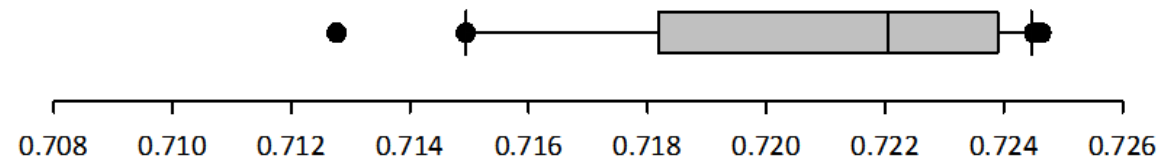

$$
{ }^{87} \mathrm{Sr} /{ }^{86} \mathrm{Sr}
$$

Figure 2. Box-plots of Sr isotopic ratio variations in channel bank and soil samples.

The lowest ratios $(0.712625$ to 0.719287$)$ were observed in the carbonate area drained by Masniers and whereas intermediate (0.719651-0.722700) and higher ratios (0.722701-0.724631) were observed in the remaining areas.

Sr isotopic ratio

- $0.712625-0.719650$

- $0.719651-0.722700$

- $0.722701-0.724631$

Simplified lithology

Carbonate substrate Silicate substrate

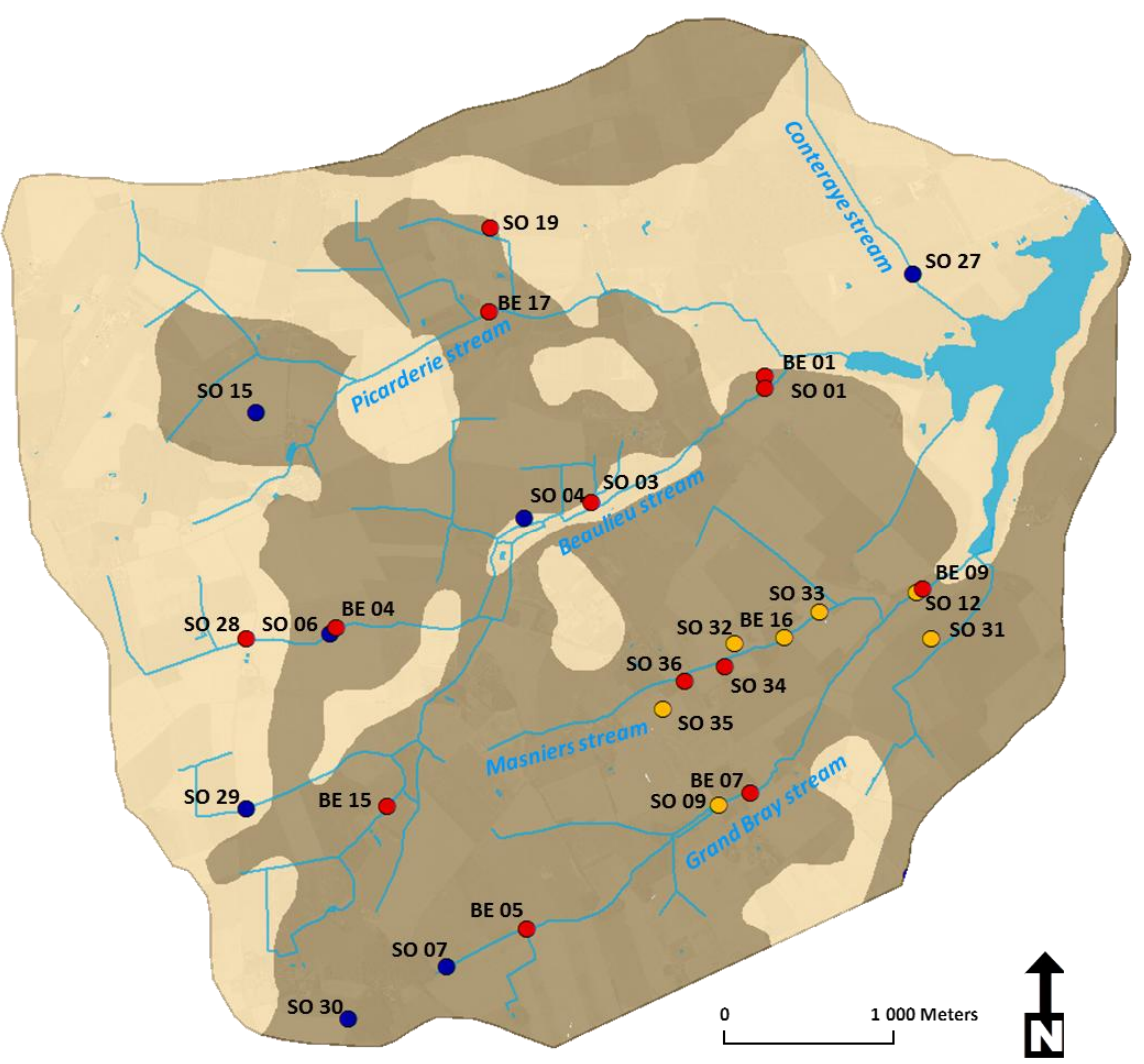

Figure 3. Location and ${ }^{87} \mathrm{Sr} /{ }^{86} \mathrm{Sr}$ ratios of soil and channel bank samples. For the soil samples, SO refers to surface samples and BE refers to channel bank samples.

\subsection{Hydrological and geochemical characterizations of suspended sediment samples}

Hydro-sedimentary parameters (i.e. water levels, turbidity) recorded during the 2013-2014 winter season were used to estimate the water discharge and suspended sediment concentration values. Unfortunately, they were only available for three monitoring stations (BE, GB, MS stations). The two first flood events were triggered by long-lasting and low-intensity rainfall and were characterized by similar suspended sediment concentrations. Water discharge recorded during the second flood were slightly lower that those recorded during the first flood, with respective maximal water discharge values of 0.76 and $0.42 \mathrm{~m}^{3} \mathrm{~s}^{-1}$ (GB station). On December 30, 2013, total precipitation reached $14 \mathrm{~mm}$ in 24 hours and suspended sediment concentrations 
varied between 15 and $624 \mathrm{mg} \mathrm{L}^{-1}$. On January 29, 2014, total precipitation reached $9.4 \mathrm{~mm}$ in 29 hours and suspended sediment concentrations varied between 2 and $416 \mathrm{mg} \mathrm{L}^{-1}$. In contrast, the third flood event that occurred on February 13, 2014 was triggered by higher precipitation ( $21.6 \mathrm{~mm}$ in 4 hours) and was more intense with higher suspended sediment concentrations and water discharge, reaching the maximal values of $2450 \mathrm{mg} \mathrm{L}^{-1}$ and $1.1 \mathrm{~m}^{3} \mathrm{~s}^{-1}$, respectively, at the BE station. Due to the higher cumulative precipitation recorded during the previous months, soils were saturated with water. The more intense rainfall event that occurred on February 13, 2014 generated erosion and sediment transport, which is illustrated by the higher water discharge and suspended sediment concentrations recorded in the river during the third monitored flood event. Suspended sediment concentrations were highly variable from one flood to another, and clockwise hysteresis was observed for the three flood events (Fig. 4). Indeed, for a given discharge, suspended sediment concentrations were higher during the rising limb compared to the falling limb.
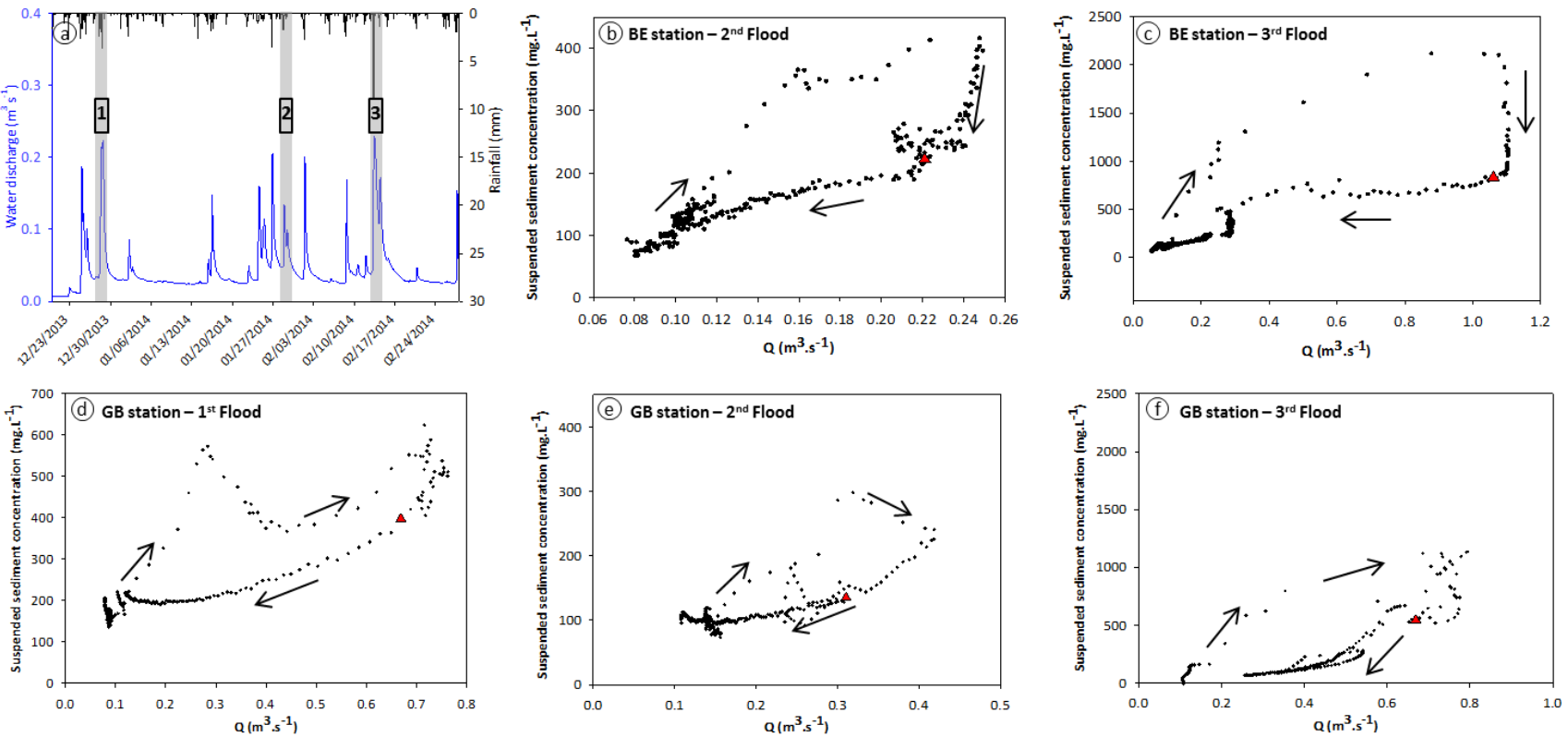

Figure 4. Water discharge and precipitation measured at the MS station during the December 2013 to the February 2014 period. Discharge and suspended sediment concentrations for the three flood events at two monitoring stations, BE and GB located in the silicate and carbonate areas and flowing to the Louroux pond. Samples collected for Sr isotopic measurements are noted by the red triangle. Data presented were respectively recorded during three days for the two first flood events and during four days for the third flood event.

During the three flood events, ${ }^{87} \mathrm{Sr} /{ }^{86} \mathrm{Sr}$ ratios measured in suspended sediment directly collected in the river and at tile drain outlets displayed large variations, with values ranging between 0.713660 and 0.720571 (Supplementary Table S2). Nevertheless, they remained within the source soil range (0.712736 to 0.724631 ). The two first flood events exhibited similar ranges of Sr isotopic variations with ratios between 0.713660 and 0.718637 . The third flood event was characterized by higher ratios ranging from 0.717814 and 0.720571 (Supplementary Table S2). For each monitoring station, ${ }^{87} \mathrm{Sr} /{ }^{86} \mathrm{Sr}$ ratios measured in suspended sediment collected during the third flood were systematically higher than those measured during the two previous floods (i.e. from 0.718637 to 0.720571 at PI station, from 0.718188 to 0.720495 at BE station, from 0.715671 to 0.717814 at MS station and from 0.716165 to 718467 at GB station).

Similarly to the sources, the lowest ${ }^{87} \mathrm{Sr} /{ }^{86} \mathrm{Sr}$ ratios were measured in suspended sediment collected in the streams $(n=6)$ and at tile drain outlets $(n=2)$ draining the carbonate areas $(0.715484$ to 0.718467 and 0.713660 to 0.714202 , respectively) mainly found in the southern part of the catchment, whereas the highest ratios were measured in suspended sediment $(n=5)$ and at tile drain outlets $(n=2)$ collected in the silicate area 
( 0.715734 to 0.720571 and 0.717296 to 0.717946 , respectively). The two lowest ratios were measured at the tile drain outlet of the BP station during the two first flood events whereas the two highest values were measured in the samples collected during the third flood at the monitoring stations of $\mathrm{BE}$ and $\mathrm{PI}$, both located in the vicinity of the silicate area. For each flood and each drained area, ${ }^{87} \mathrm{Sr} /{ }^{86} \mathrm{Sr}$ ratios measured in suspended sediment collected at tile drain outlets were systematically lower than those measured in suspended sediment directly collected in the stream (Supplementary Table S2).

\subsection{Relationship between ${ }^{87} \mathrm{Sr} /{ }^{86} \mathrm{Sr}$ and elemental ratios in source and suspended sediment samples - end-member selection}

A Hierarchical Cluster Analysis (HCA) was performed using ${ }^{87} \mathrm{Sr} /{ }^{86} \mathrm{Sr}$ ratios, $\mathrm{Na}, \mathrm{Mg}, \mathrm{K}, \mathrm{Ca}$, Rb and $\mathrm{Sr}$ concentrations measured in channel bank and soil samples. The results indicate that source samples can be grouped in two major clusters (Fig. S1). The first cluster (Group 1, n=4) contains samples with the highest $\mathrm{Ca}$ and $\mathrm{Sr}$ concentrations and ${ }^{87} \mathrm{Sr} /{ }^{86} \mathrm{Sr}$ ratios ranging between 0.712625 and 0.716986 . These samples (SO31, SO32, SO33, BE16) are all located in the carbonate/southern area of the catchment. The second cluster (Group 2, $\mathrm{n}=24$ ) is divided into several sub-clusters. In these samples, ${ }^{87} \mathrm{Sr} /{ }^{86} \mathrm{Sr}$ ratios are generally higher and $\mathrm{Ca}$ and $\mathrm{Sr}$ concentrations are lower than in samples of the first group. Their $\mathrm{Na}, \mathrm{Mg}, \mathrm{K}$ and $\mathrm{Rb}$ concentrations are variable.

To improve the discrimination of suspended sediment sources, the variations of ${ }^{87} \mathrm{Sr} /{ }^{86} \mathrm{Sr}$ and elemental ratios were investigated using scatter plots (Fig. 5). Soil and suspended sediment samples exhibited large variations in ${ }^{87} \mathrm{Sr} /{ }^{86} \mathrm{Sr}$ and chemical element ratios, suggesting that they were supplied by contrasting soil sources. High $\mathrm{Ca} / \mathrm{Sr}$ combined with low $\mathrm{K} / \mathrm{Sr}, 1 / \mathrm{Sr}, \mathrm{Rb} / \mathrm{Sr}$ and $\mathrm{Na} / \mathrm{Sr}$ ratios indicated a carbonate component whereas low $\mathrm{Ca} / \mathrm{Sr}$ associated with high $\mathrm{K} / \mathrm{Sr}, 1 / \mathrm{Sr}, \mathrm{Rb} / \mathrm{Sr}$ and $\mathrm{Na} / \mathrm{Sr}$ ratios were indicative of a silicate component. The first group of soil samples (SO31, SO32, SO33, BE16) displayed contrasting ${ }^{87} \mathrm{Sr} /{ }^{86} \mathrm{Sr}$ and elemental ratios compared to those of the second cluster. Furthermore, two additional source samples (SO12, SO35) from the second cluster indicated by a red arrow in Fig. 5 exhibited ${ }^{87} \mathrm{Sr} /{ }^{86} \mathrm{Sr}$ and elemental ratio values comparable to those of the soil samples from the first cluster.

These six soil samples (BE16, SO12, SO31; SO32, SO33 and SO35, represented with black circles on Fig. 5) were discriminated from the remaining soil samples and characterized by lower ${ }^{87} \mathrm{Sr} /{ }^{86} \mathrm{Sr}, \mathrm{K} / \mathrm{Sr}, 1 / \mathrm{Sr}, \mathrm{Rb} / \mathrm{Sr}$ and $\mathrm{Na} / \mathrm{Sr}$ ratios (Fig. $5 \mathrm{a}, \mathrm{c}, \mathrm{d}$ ) and higher $\mathrm{Ca} / \mathrm{Sr}$ ratios (Fig. $5 \mathrm{~b}, \mathrm{e}$ ). $\mathrm{Mg} / \mathrm{Sr}$ ratios did not discriminate between the two sources as the mean $\mathrm{Mg} / \mathrm{Sr}$ ratios estimated in carbonate soils and silicate soils were similar. These six soil samples displayed the lowest ${ }^{87} \mathrm{Sr} /{ }^{86} \mathrm{Sr}$ ratios (between 0.712625 and 0.717815 ) suggesting a higher carbonate component compared to the remaining soil samples. Consequently, they were classified as carbonate soil samples and the remaining samples as silicate soil samples.

Suspended sediment samples did not plot along a mixing line between the carbonate and silicate soil source samples with the exception of suspended sediment from the third flood event that plotted with soil samples using $\mathrm{Rb} / \mathrm{Sr}$ ratios (Fig. $5 \mathrm{~d}$ ). The ${ }^{87} \mathrm{Sr} /{ }^{86} \mathrm{Sr}$ ratios therefore were measured in the $<63 \mu \mathrm{m}$ and $<2 \mu \mathrm{m}$ fractions of select soil samples $(n=8)$ (Supplementary Tables S3-4-5). The ${ }^{87} \mathrm{Sr} /{ }^{86} \mathrm{Sr}$ ratios in the $<63 \mu \mathrm{m}$ fraction $(0.716178$ 0.724667) were slightly higher than in the $<2 \mathrm{~mm}$ fraction but elemental ratios were slightly lower or higher depending on soil samples. Suspended sediment samples did not match with the $<63 \mu \mathrm{m}$ fraction of soil source samples. However, ${ }^{87} \mathrm{Sr} /{ }^{86} \mathrm{Sr}$ ratios in the $<2 \mu \mathrm{m}$ fraction were even lower than in the $<63 \mu \mathrm{m}$ fraction, with ratios ranging between 0.713099 and 0.722535 and suspended sediment samples plotted with the $<2$ $\mu \mathrm{m}$ fraction of soil samples using $\mathrm{K} / \mathrm{Sr}, \mathrm{Ca} / \mathrm{Sr}, 1 / \mathrm{Sr}, \mathrm{Rb} / \mathrm{Sr}$ and $\mathrm{Mg} / \mathrm{Sr}$ elemental ratios. This was not observed 
354 for $\mathrm{Na} / \mathrm{Sr}$ ratios which have very high values (524-1170) and were thus enriched $\mathrm{Na}$ concentrations in the $355<2$ um fraction relative to the other samples.
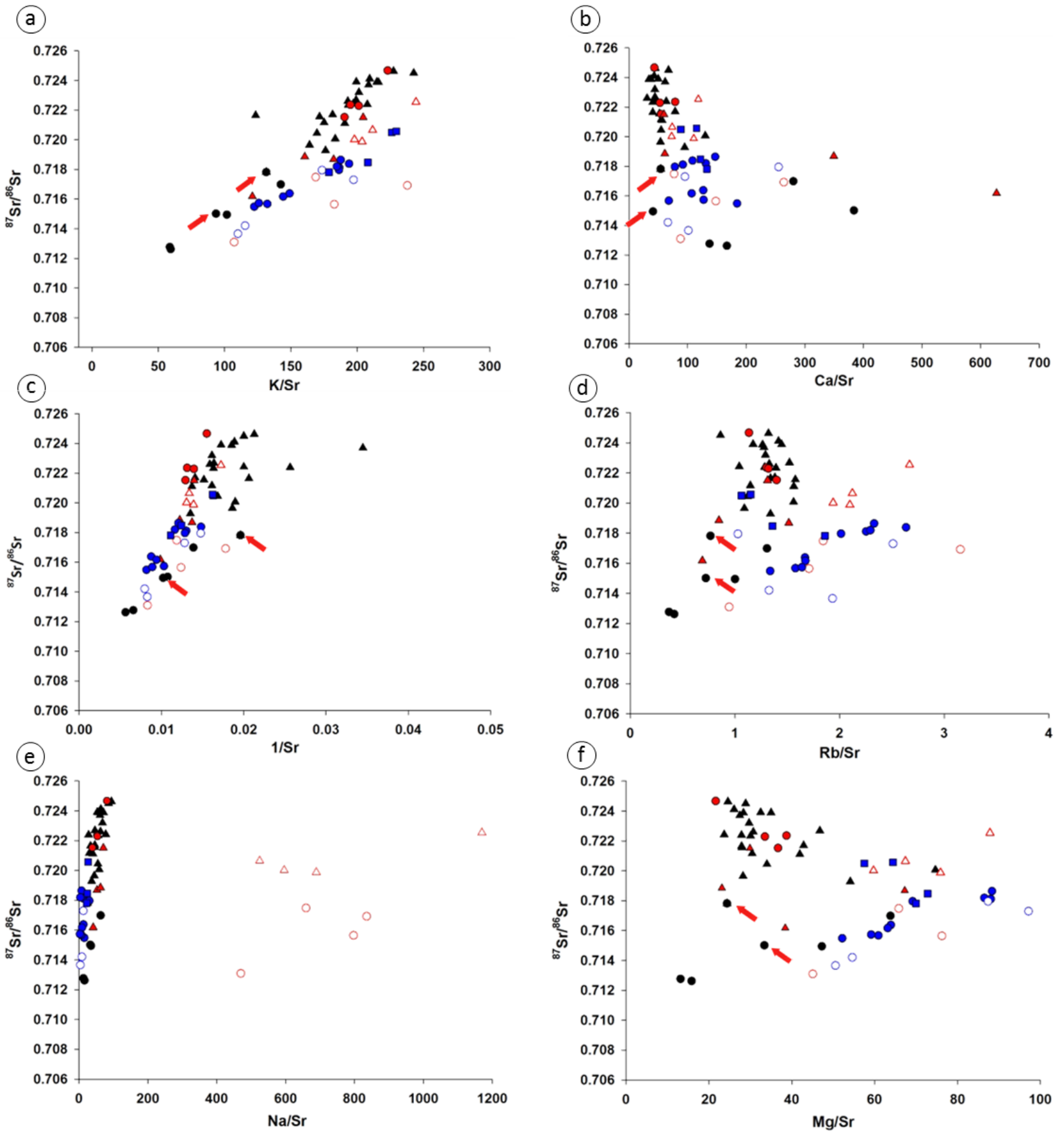

- Bulk soil samples (carbonate component)

A Bulk soil samples (silicate component)

- $<63 \mu \mathrm{m}$ soil samples (carbonate component)

$\Delta<63 \mu \mathrm{m}$ soil samples (silicate component)
$<2 \mu \mathrm{m}$ soil samples (carbonate component)
$\Delta<2 \mu \mathrm{m}$ soil samples (silicate component)
- Suspended sediment $-1^{\text {st }}$ and $2^{\text {nd }}$ floods (river waters)
Suspended sediment $-1^{\text {st }}$ and $2^{\text {nd }}$ floods (river waters)

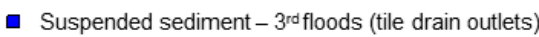

Figure $5 .{ }^{87} \mathrm{Sr} /{ }^{86} \mathrm{Sr}$ vs $\mathrm{K} / \mathrm{Sr}(\mathrm{a}), \mathrm{Ca} / \mathrm{Sr}(\mathrm{b}), 1 / \mathrm{Sr}$ (c), $\mathrm{Rb} / \mathrm{Sr}$ (d), $\mathrm{Sr} / \mathrm{Na}$ (e) and $\mathrm{Mg} / \mathrm{Sr}$ (f) for suspended sediment, $<2 \mathrm{~mm},<63 \mu \mathrm{m}$ and $<2$ $\mu \mathrm{m}$ fraction of soil samples. Red arrows indicate the two soil additional soil samples used to define the carbonate end-member using scatter plots. 
362 In this cultivated catchment, results indicated that $\mathrm{Sr}$ isotopic signatures varied according to the particle size 363 fraction analyzed (i.e. $<2 \mathrm{~mm},<63 \mu \mathrm{m}$ and $<2 \mu \mathrm{m}$ ). Accordingly, suspended sediment may be interpreted as a 364 mixture of two end-members characterized by different source soil particle size fractions depending on the 365 flood intensity.

366

367 368 369 370 371 372 373 374 375 376 377 378 379 380 381 382 383 384

$\mathrm{Sr}$ isotopic signatures significantly discriminated between the $<2 \mathrm{~mm}$ fraction of soil samples and suspended sediment from the two first flood events ( $M W p=0.000$ ) though not the last flood event ( $M W p=0.172$ ). This suggests, in combination with the figures above (Fig. 3 and Fig. 5), that the $<2 \mathrm{~mm}$ fraction of soil samples could be used as a source of suspended sediment during the last flood event. Mann-Whitney tests were then performed to assess the ability of ${ }^{87} \mathrm{Sr} /{ }^{86} \mathrm{Sr}$ ratios to discriminate between the $<2 \mathrm{~mm}$ fraction of soil samples and the $<63$ and $<2 \mu \mathrm{m}$ fractions, respectively. Results reported the absence of significant differences between the $<2 \mathrm{~mm}$ and $<63 \mu \mathrm{m}$ fractions (MW $p=0.115$ ) but they showed significant differences between the $<2 \mathrm{~mm}$ and $<2 \mu \mathrm{m}$ fractions (MW $p<0.042$ ). Furthermore, no significant difference was observed between the $<2 \mu \mathrm{m}$ fraction of soil and suspended sediment collected during the two first flood events ( $M W p=0.242$ ). These results suggest that the $<2 \mu \mathrm{m}$ and the $<2 \mathrm{~mm}$ fraction of soil samples should be modelled as suspended sediment sources depending on hydrological conditions in the Louroux catchment as they control the particle size fractions transported in suspension.

As ${ }^{87} \mathrm{Sr} /{ }^{86} \mathrm{Sr}$ ratios measured in soil samples reflect the mixing of carbonate and silicate source soils, the respective contributions of these two end-members to the suspended sediment were modelled (Eq. 1). ${ }^{87} \mathrm{Sr} /{ }^{86} \mathrm{Sr}$ ratios and $\mathrm{Sr}$ concentrations measured in the $<2 \mu \mathrm{m}$ and in the $<2 \mathrm{~mm}$ fractions of soil samples were used to respectively investigate end-members contributions during the two first flood events and during the third flood event.

Table 1. Mean and Standard Deviation for Sr isotopic signatures, Sr concentrations $\left(\mathrm{mg} \mathrm{kg}^{-1}\right)$ for the different end-members.

\begin{tabular}{cccc}
\hline & End-Members & ${ }^{87} \mathrm{Sr} /{ }^{86} \mathrm{Sr}$ & $\mathrm{Sr}$ \\
\hline$<2 \boldsymbol{\mu m}$ & Carbonate soil samples & $0.715222 \pm 7$ & $86 \pm 7$ \\
Fraction & Silicate soil samples & $0.720113 \pm 8$ & $73 \pm 6$ \\
\hline$<2 \mathbf{m m}$ & Carbonate soil samples & $0.715024 \pm 8$ & $107 \pm 9$ \\
Fraction & Silicate soil samples & $0.722316 \pm 17$ & $55 \pm 4$ \\
\hline
\end{tabular}

Results (Fig. 6a,b,c) indicate that carbonate soil contributions were the highest during the two first flood events when the $<2 \mu \mathrm{m}$ fraction contributed to suspended sediment (mean carbonate contributions of $61 \%$ and $65 \%$ ) compared to the third flood where the $<2 \mathrm{~mm}$ fraction of silicate soils contributed the highest proportions to the suspended sediment (mean silicate contribution of 72\%) (Fig. 6, Supplementary Table S6 for all modelling results).

For the two first flood events, the $<2 \mu \mathrm{m}$ fraction of the carbonate source soil end-member had the highest contributions, estimated between $73 \%$ to the GB station and $100 \%$ to the BR station, to the suspended sediment collected in the carbonate area located in the southern part of the catchment. In the northern part of the catchment, the silicate soil contributions remained in the same order of magnitude during the two first flood events with respective mean silicate contributions of $59 \%$ and $52 \%$. During the third flood event, the $<2$ $\mathrm{mm}$ silicate soil end-member contributed the most to suspended sediment with contributions ranging between $55 \%$ and $86 \%$, with a mean contribution of $72 \%$. 


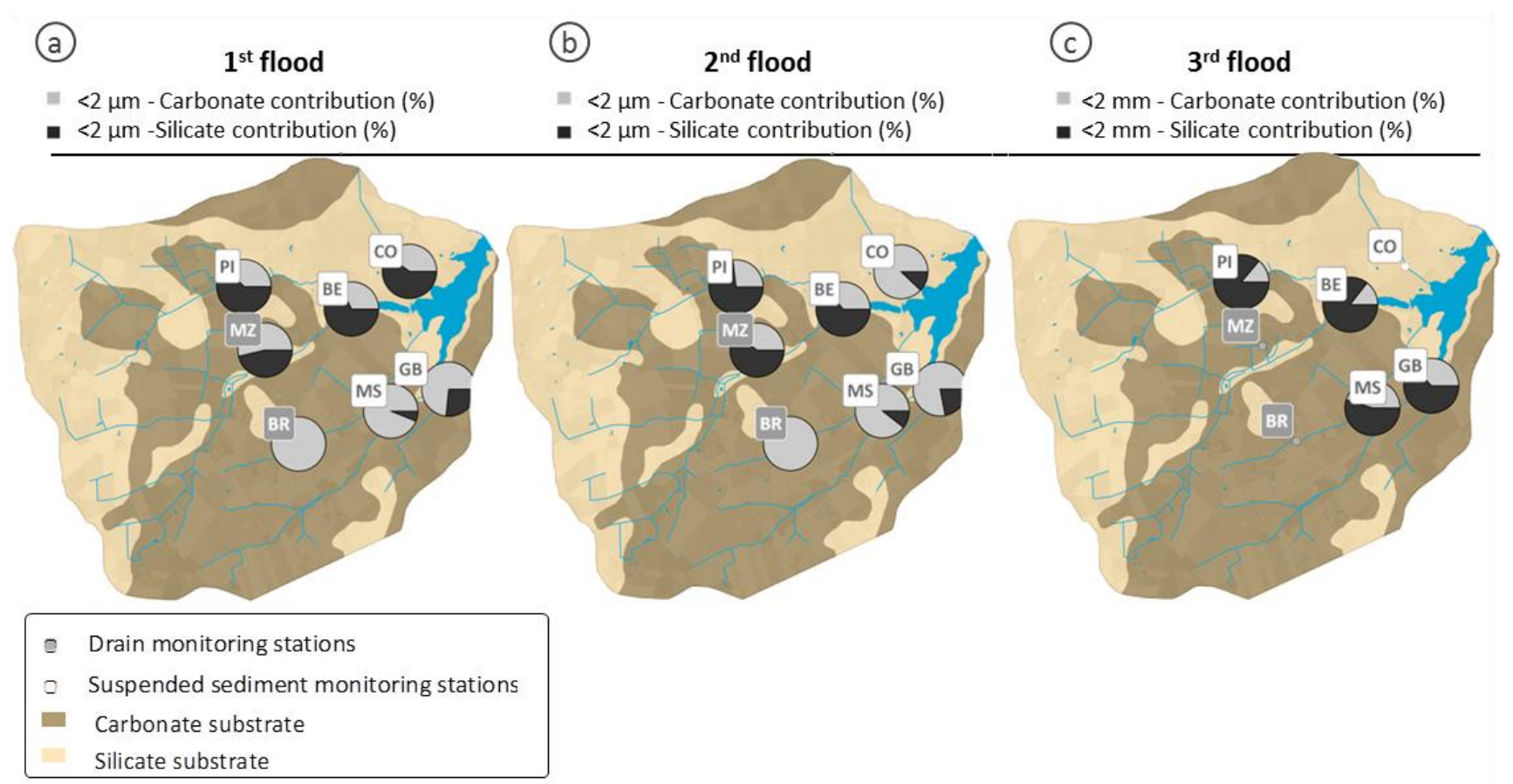

Figure 6. Carbonate and silicate soil contributions (\%) to suspended sediment using ${ }^{87} \mathrm{Sr} /{ }^{86} \mathrm{Sr}$ ratios measured in the $<2 \mu \mathrm{m}$ fraction for the two first flood events ( $a$ and $b$ ) and in the $<2 \mathrm{~mm}$ fraction for the third flood event (c).

\section{Discussion}

\subsection{Temporal variability of suspended sediment characteristics and source effect}

\subsubsection{Impact of flood events on suspended sediment transport}

In the Louroux catchment, suspended sediment concentrations and water discharge exhibited clockwise hysteresis loops during the three flood events. Hysteresis patterns characterize suspended sediment stock and exhaustion and are commonly used to investigate their sources during floods (Williams, 1989; Sherriff et al., 2016). Clockwise hysteresis loops suggest that suspended sediment originates from a close source and reflects the progressive decline in suspended sediment availability. They are commonly attributed to a depletion of available sediment before the maximum discharge is reached (Walling, 1977; Horowitz, 2008). Accordingly, suspended sediment transported in the Louroux catchment during the three flood events may correspond to material previously accumulated in the river bed and easily remobilized during the rising limb of the flood and/or to sediment that originated from eroded sources located relatively close to the monitoring stations.

Suspended sediment exported from local sources depends on the quantity of sediment previously stored in the river channels. In agricultural lowland catchments, higher suspended sediment concentrations may be observed in winter due to the higher sensitivity of soils to erosion during this season (Delmas et al., 2011). A previous study demonstrated that in the Louroux catchment, suspended sediment transported during floods almost exclusively originate from surface sources (Foucher et al., 2015), suggesting that the clockwise hysteresis loops observed may be attributed to the erosion of local surface sources, transiting the highly connected drainage network, rather than to the resuspension of channel bed sediment as observed in lowland catchments in the UK (Evans et al., 2003; Collins and Walling, 2006). 


\subsubsection{Source discrimination with ${ }^{87} \mathrm{Sr} /{ }^{86} \mathrm{Sr}$ ratios}

${ }^{87} \mathrm{Sr} /{ }^{86} \mathrm{Sr}$ ratios have been commonly used in sediment provenance studies in large river basins. However, less attention has been focused on local, small-scale catchments. Indeed, using ${ }^{87} \mathrm{Sr} /{ }^{86} \mathrm{Sr}$ ratios may be challenging at smaller scales because of potential local heterogeneities, which may be homogenized in larger scale research. In the Louroux catchment, ${ }^{87} \mathrm{Sr} /{ }^{86} \mathrm{Sr}$ ratios measured in soil and suspended sediment samples presented significant variations and highlighted the utility of using this tracer for tracing sediment source dynamics at smaller spatial scales.

In this study, ${ }^{87} \mathrm{Sr} /{ }^{86} \mathrm{Sr}$ ratios measured in soil and suspended sediment samples varied according to the particle size and to the hydrological conditions. $A{ }^{87} \mathrm{Sr} /{ }^{86} \mathrm{Sr}$ ratios measured in the suspended sediment did not plot along a mixing line between the carbonate and silicate $<2 \mathrm{~mm}$ soil samples, $\mathrm{Sr}$ isotopic signatures were investigated in the $<63$ and $<2 \mu \mathrm{m}$ fractions of soil samples. When investigating ${ }^{87} \mathrm{Sr} /{ }^{86} \mathrm{Sr}$ ratios versus elemental ratios $(\mathrm{K} / \mathrm{Sr}, \mathrm{Ca} / \mathrm{Sr}, 1 / \mathrm{Sr}, \mathrm{Rb} / \mathrm{Sr})$, the $<2 \mu \mathrm{m}$ fraction of soil samples was shown to provide a more appropriate source for suspended sediment transported in the river network. $\mathrm{Na} / \mathrm{Sr}$ ratios did not discriminate between the different soil fractions and suspended sediment samples. Indeed, the $<2 \mu \mathrm{m}$ fraction of soil samples was enriched in Na compared to suspended sediment samples (Supplementary Tables S3 and S5). These high concentrations may be explained by a supply in Na originating from the deionized water used to isolate the $<2 \mu \mathrm{m}$ particles. This contamination may have induced the crystallization of minerals containing $\mathrm{Na}$ on fine particles, such as clays, when the solutions with $<2 \mu \mathrm{m}$ particles were dried. Overall, the use of ${ }^{87} \mathrm{Sr} /{ }^{86} \mathrm{Sr}$ and $\mathrm{Rb} / \mathrm{Sr}$ ratios provided the best discrimination between suspended sediment samples and between the different soil fractions. A clear discrimination between suspended sediment samples from the two first flood events with signatures similar to that of the $<2 \mu \mathrm{m}$ fraction of soil samples and suspended sediment from the third flood event with signatures similar to that of the $<2 \mathrm{~mm}$ fraction of soil samples was observed (Fig. 7).

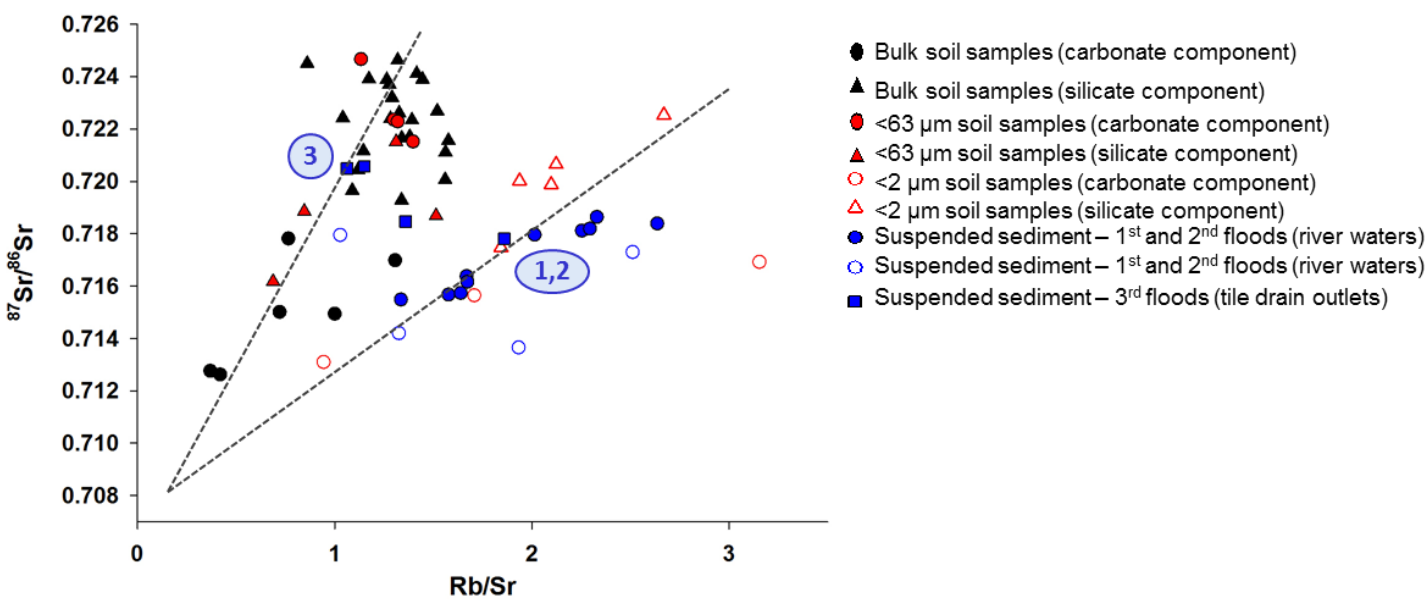

Figure $7 .{ }^{87} \mathrm{Sr} /{ }^{86} \mathrm{Sr}$ vs $\mathrm{Rb} / \mathrm{Sr}$ in suspended sediment, carbonate and silicate soil samples ( $<2 \mathrm{~mm},<63 \mu \mathrm{m}$ and $<2 \mu \mathrm{m}$ fractions). 1,2,3: suspended sediment sampling campaign number.

These results indicate that in the Louroux catchment, suspended sediment collected during the two first floods, which plotted with the $<2 \mu \mathrm{m}$ fraction of soil samples, corresponded to fine particles whereas suspended sediment from the third flood, that plotted with $<2 \mathrm{~mm}$ soil samples, corresponded to a coarser fraction. The particle size composition of fine sediment exerts a significant control on its mineralogy and geochemistry. According to Walling et al. (2000), material sieved to $<2 \mu \mathrm{m}$ will be mainly composed of primary or secondary silicate minerals, whereas larger particle size fractions will be dominated by quartz. 
456 Results of the current research indicate that the $<2 \mu \mathrm{m}$ fraction of soil samples is characterized by a significant increase of the $\mathrm{Rb} / \mathrm{Sr}$ ratios and a decrease or a stagnation of ${ }^{87} \mathrm{Sr} /{ }^{86} \mathrm{Sr}$ ratios compared to those measured in larger particle size fractions. These variations illustrate differences in the mineralogy of the analyzed particle size fractions. The increase of $\mathrm{Rb} / \mathrm{Sr}$ ratios in the $<2 \mu \mathrm{m}$ fraction likely reflects an enrichment in secondary minerals, such as clays. However, to strengthen the $\mathrm{Sr}$ isotopic discrimination between the different particle size fractions of soils and the suspended sediment samples according to flood events, additional mineralogical analyses should be performed on the $<2 \mu \mathrm{m},<63 \mu \mathrm{m}$ and $<2 \mathrm{~mm}$ fractions of soil samples, suspended sediment and separate minerals. The particle size distribution in soil samples should also be investigated to evaluate the proportion of the $<2 \mu \mathrm{m}$ fraction compared to the coarser fractions. Mineralogical and particle size measurements related to ${ }^{87} \mathrm{Sr} /{ }^{86} \mathrm{Sr}$ values could provide additional information, demonstrating that very fine particles were transported through this river network.

467 468 469

\subsection{Variations in source contributions to suspended sediment and modelling implications}

To estimate the relative contribution of the $<2 \mu \mathrm{m}$ and $<2 \mathrm{~mm}$ fractions of carbonate and silicate soils to suspended sediment depending on the flood event, a mixing equation incorporating ${ }^{87} \mathrm{Sr} /{ }^{86} \mathrm{Sr}$ ratios and $\mathrm{Sr}$ concentrations was used. This approach illustrated the interest of conducting ${ }^{87} \mathrm{Sr} /{ }^{86} \mathrm{Sr}$ ratio measurements in different particle size fractions and under varying hydrological conditions. Although several studies have used geochemical properties (mostly major and trace element concentrations) in mixing models to estimate the contribution of different lithological sources (Olley and Caitcheon, 2000; Douglas et al., 2003; Evrard et al., 2011; Navratil et al., 2012b) or investigated the relation between the chemical and isotopic composition of the sediment transported under varying hydrological conditions and their particle size distribution (Bouchez et al., 2011a; Bouchez et al., 2011b; Lupker et al., 2011), fewer studies estimated sediment sources contributions after conducting geochemical measurements on different particle size fractions of source material (Navratil et al., 2012; Haddadchi et al., 2015).

The preliminary results obtained in the Louroux catchment showed the importance of modelling and estimating source contributions to the suspended sediment with different particle size fractions depending on the flood intensities. These results highlighted that sediment fingerprinting approaches conducted in this catchment and in other similar environments should target multiple particle size fractions: the $<2 \mu \mathrm{m}$ fraction in lower intensity events, and during more intense floods when a coarser fraction of sediment is transported, the $<2 \mathrm{~mm}$ fraction of soil samples should be used to characterize the potential sources of sediment. Ultimately, the variations of $\mathrm{Sr}$ isotopic signatures observed in the different particle size fractions also indicated that ${ }^{87} \mathrm{Sr} /{ }^{86} \mathrm{Sr}$ ratios are not a straightforward tracer of sediment sources in this catchment. Indeed, the ${ }^{87} \mathrm{Sr} /{ }^{86} \mathrm{Sr}$ ratio must be traced across multiple particle size fractions in order to provide sediment source material. It is likely that there are other sediment fingerprint parameters that require a particle size fraction specific approach to accurately quantify sediment source dynamics.

\subsection{Sediment transfer through the drainage network}

The ${ }^{87} \mathrm{Sr} /{ }^{86} \mathrm{Sr}$ ratios were an effective tracer of suspended sediment sources when incorporating particle size. However, the specific role of the drainage network in the transport and the supply of sediment from tile drains to the river remains difficult to quantify. Sr isotopic measurements revealed that strong variations in signatures were observed in the different fractions of soils and in suspended sediment over the three flood events in the Louroux catchment. Hillslopes and drains mainly supplied very fine (clay-sized) particles to the rivers. Accordingly, the Sr isotopic signatures of suspended sediment coincided with the signatures of the $<2$ 
$\mu \mathrm{m}$ fraction of soil samples during the two first floods. The dense drainage system, with more than 220 tile drain outlets found across the catchment, could provide the main pathway for sediment delivery to the rivers during these events. These findings are consistent with the results obtained by Foucher et al. (2015), who found that sediment exported from the drains was modelled to originate almost exclusively from surface sources ( $99 \pm 2.5 \%$ ), suggesting that the drainage system facilitates the transfer of particles from the soil surface to the rivers in this cultivated catchment. The elevated contribution of the drainage system in the delivery of sediment to the rivers was also highlighted by other studies conducted in France and in the UK (Sogon et al., 1999; Russell et al., 2001; Walling et al., 2002). However, the migration of particles through the soil profile still remains poorly documented although the presence of macropores was suggested to provide a preferential pathway for particle transport in these drained environments (Walling et al., 2002; Jagercikova et al., 2014).

$\mathrm{Sr}$ isotopes were used to provide additional information on the sources of material transiting the drains. Lower ${ }^{87} \mathrm{Sr} /{ }^{86} \mathrm{Sr}$ ratios were observed between the $<2 \mathrm{~mm}$ and $<2 \mu \mathrm{m}$ fractions of soil samples. ${ }^{87} \mathrm{Sr} /{ }^{86} \mathrm{Sr}$ ratios measured in suspended sediment collected at tile drain outlets were lower than the ratios measured in suspended sediment directly collected in the river and even lower for the BR station than most of the signatures measured in the $<2 \mu \mathrm{m}$ fraction of soil samples, suggesting that the material transiting the drain may be finer than $2 \mu \mathrm{m}$. These downward trends observed in ${ }^{87} \mathrm{Sr} /{ }^{86} \mathrm{Sr}$ ratios may indicate that particles transiting the drains are finer than most particles transported in the river. This is consistent with a previous study demonstrating that sediment exported by the drainage system was enriched in ${ }^{137} \mathrm{Cs}$ compared to soil samples. A significant particle size selection process likely occurs in the soil profile, with the migration of the finest particles through the drainage system (Foucher et al., 2014). Particle size measurements also showed that suspended sediment collected at tile drain outlets were very fine, with $50 \%$ of the particles having a diameter lower than $1 \mu \mathrm{m}$ (S. Salvador-Blanes, unpublished results), which is consistent with our observations.

These results highlighted the importance of considering tile drains as a preferential source of sediment. The material transiting the drainage system and contributing to the supply of sediment to the rivers consists of very fine material $(<2 \mu \mathrm{m})$ originating from surface soils. Accordingly, it is crucial to improve the management of the drain system in order to reduce the amount of sediment that they supply to the rivers. This is particularly true in winter, when flow from the drains is high and contributes significantly to sediment export.

\section{Conclusions}

This study highlighted the potential of Sr isotope measurements to identify suspended sediment sources and quantify their dynamics. ${ }^{87} \mathrm{Sr} /{ }^{86} \mathrm{Sr}$ ratios were used to discriminate between the potential sources of suspended sediment and to identify differences in their characteristics depending on flood intensity. ${ }^{87} \mathrm{Sr} /{ }^{86} \mathrm{Sr}$ ratios measured in suspended sediment varied in space and time reflecting changes in sources. The $\mathrm{Sr}$ isotopic signatures significantly varied in the different fractions of soil samples (i.e $<2 \mathrm{~mm},<63 \mu \mathrm{m}$, and $<2$ $\mu \mathrm{m})$ and in suspended sediment, reflecting the preferential transfer of fine particles during sediment transport in the Louroux catchment. The particle size of sediment transiting the river network changes with hydrological conditions and our results suggest it may be important to fractionate source material to different particle sizes depending on flood intensity.

A preliminary modeling approach used ${ }^{87} \mathrm{Sr} /{ }^{86} \mathrm{Sr}$ ratios and $\mathrm{Sr}$ concentrations to estimate the relative contribution of sources to the suspended sediment. Results demonstrated that different particle size 
541 fractions of sources can be used to estimate their respective contributions to the suspended sediment 542 depending on hydrological conditions. Very fine sediment was shown to be exported from the tile drains, 543 which demonstrates the need to better manage material supplied by tile drains to the river network. The 544 creation of retention ponds could for instance trap this fine material and prevent it from reaching the river 545 system.

546 These results highlighted the need to focus on the geochemical composition of soils instead of bedrock 547 lithology to potentially better constrain sediment sources and pathways at the catchment scale in intensively 548 cultivated environments. These investigations will improve our understanding of soil erosion processes and 549 sediment supply in similar catchments. In the future, material separated to different particle size fractions 550 could be used to identify the sources supplying sediment during floods of varying magnitude. For a better representativeness, suspended sediment should be monitored with high resolution sampling to characterize geochemical $\left({ }^{87} \mathrm{Sr} /{ }^{86} \mathrm{Sr}\right.$, elemental concentrations) and potential source variations over one single flood event. 553 Additional radionuclide measurements $\left({ }^{137} \mathrm{Cs},{ }^{210} \mathrm{~Pb}_{\mathrm{xs}},{ }^{7} \mathrm{Be}\right)$ should also be conducted in order to identify parameters that may help better discriminate the contribution of tile drain material to rivers.

555

556

557

558

559

560

561

562

563

564

565

566

567

568

569

570

571

572

573

574

575

576

577

578

579

580

581

582

583

\section{Acknowledgements}

This work received financial support from the Loire-Brittany Water Agency (TrackSed and Drastic projects). Marion Le Gall received a PhD fellowship from CEA (Commissariat à I'Energie Atomique et aux Energies Alternatives, France) and the DGA (Direction Générale de l'Armement, France), French MoD.

\section{References}

Albarède, F., 1995. Introduction to Geochemical Modeling. Cambridge University Press.

Allègre, C.J., Dupr, B., Philippe, N., Gaillardet, J., 1996. Sr-Nd-Pb isotope systematics in Amazon and Congo River systems : Constraints about erosion processes. Chemical Geology, 131: 93-112.

Asahara, Y., Tanaka, T., Kamioka, H., Nishimura, A., Yamazaki, T., 1999. Provenance of the north Pacific sediments and process of source material transport as derived from $\mathrm{Rb}-\mathrm{Sr}$ isotopic systematics. Chemical Geology, 158: 271-291.

Audry, S., Schafer, J., Blanc, G., Jouanneau, J.M., 2004. Fifty-year sedimentary record of heavy metal pollution $(\mathrm{Cd}, \mathrm{Zn}, \mathrm{Cu}, \mathrm{Pb})$ in the Lot River reservoirs (France). Environmental Pollution, 132(3): 413-26.

Beusen, A.H.W., Dekkers, A.L.M., Bouwman, A.F., Ludwig, W., Harrison, J., 2005. Estimation of global river transport of sediments and associated particulate C, N, and P. Global Biogeochemical Cycles, 19(4).

Bouchez, J., Gaillardet, J., France-Lanord, C., Maurice, L., Dutra-Maia, P., 2011a. Grain size control of river suspended sediment geochemistry: Clues from Amazon River depth profiles. Geochemistry, Geophysics, Geosystems, 12(3).

Bouchez, J., Métivier, F., Lupker, M., Maurice, L., Perez, M., Gaillardet, J., France-Lanord, C., 2011b. Prediction of depth-integrated fluxes of suspended sediment in the Amazon River: particle aggregation as a complicating factor. Hydrological Processes, 25(5): 778-794.

Brennan, S.R., Fernandez, D.P., Mackey, G., Cerling, T.E., Bataille, C.P., Bowen, G.J., Wooller, M.J., 2014. Strontium isotope variation and carbonate versus silicate weathering in rivers from across Alaska: Implications for provenance studies. Chemical Geology, 389: 167-181.

Brenot, A., Baran, N., Petelet-Giraud, E., Négrel, P., 2008. Interaction between different water bodies in a small catchment in the Paris basin (Brévilles, France): Tracing of multiple Sr sources through $\mathrm{Sr}$ isotopes coupled with $\mathrm{Mg} / \mathrm{Sr}$ and $\mathrm{Ca} / \mathrm{Sr}$ ratios. Applied Geochemistry, 23(1): 58-75. 
Chartin, C., Evrard, O., Onda, Y., Patin, J., Lefèvre, I., Ottlé, C., Ayrault, S., Lepage, H., Bonté, P., 2013. Tracking the early dispersion of contaminated sediment along rivers draining the Fukushima radioactive pollution plume. Anthropocene, 1: 23-34.

Collins, A.J., Walling, D.E., 2006. Investigating the remobilization of fine sediment stored on the channel bed of lowland permeable catchments in the UK. Sediment Dynamics and the Hydromorphology of Fluvial Systems (Proceedings of a symposium, IAHS): 471-479.

Collins, A.J., Walling, D.E., Leeks, G.J.L., 1997. Source type ascription for fluvial suspended sediment based on a quantitative composite fingerprinting technique. Catena, 29: 1-27.

Collins, A.L., Zhang, Y., Walling, D.E., Grenfell, S.E., Smith, P., 2010. Tracing sediment loss from eroding farm tracks using a geochemical fingerprinting procedure combining local and genetic algorithm optimisation. Science of the Total Environment, 408(22): 5461-71.

Coynel, A., Schäfer, J., Blanc, G., Bossy, C., 2007. Scenario of particulate trace metal and metalloid transport during a major flood event inferred from transient geochemical signals. Applied Geochemistry, 22(4): 821-836.

Delmas, M., Cerdan, O., Cheviron, B., Mouchel, J.M., 2011. River basin sediment flux assessments. Hydrological Processes, 25(10): 1587-1596.

Douglas, G., Gray, C.M., Hart, B., Beckett, R., 1995. A strontium isotopic investigation of the origin of suspended particulate matter (SPM) in the Murray-Darling River system, Australia. Geochimica et Cosmochimica Acta, 59(18): 3799-3815.

Eikenberg, J., Tricca, A., Vezzu, G., Stille, P., Bajo, S., Ruethi, M., $2001 .{ }^{228} \mathrm{Ra} /{ }^{226} \mathrm{Ra} /{ }^{224} \mathrm{Ra}$ and ${ }^{87} \mathrm{Sr} /{ }^{86} \mathrm{Sr}$ isotope relationship for determining intercations between ground and river water in the upper Rhine valley. Journal of Environmental Radioactivity, 54: 133-162.

European Environment Agency, 2002. EEA-ETC/TE 2002. CORINE land cover update. I\&CLC2000 project. Technical Guidelines (http://terrestrial.eionet.eu.int).

Evans, D.J., Johnes, P., Lawrence, D.S., 2003. Suspended and bed load sediment transport dynamics in two lowland UK streams-storm integrated monitoring. Erosion and sediment transport measurment in rivers: technological and methodological advances. International Association of Hydrological Sciences: 103-110.

Evrard, O., Navratil, O., Ayrault, S., Ahmadi, M., Némery, J., Legout, C., Lefèvre, I., Poirel, A., Bonté, P., Esteves, M., 2011. Combining suspended sediment monitoring and fingerprinting to determine the spatial origin of fine sediment in a mountainous river catchment. Earth Surface Processes and Landforms, 36(8): 1072-1089.

Faure, G., 1986. Principles of Isotopic Geology. Wiley, New York.

Foucher, A., Laceby, J.P., Salvador-Blanes, S., Evrard, O., Le Gall, M., Lefevre, I., Cerdan, O., Rajkumar, V., Desmet, M., 2015. Quantifying the dominant sources of sediment in a drained lowland agricultural catchment: the application of a thorium-based particle size correction in sediment fingerprinting. Geomorphology.

Foucher, A., Salvador-Blanes, S., Evrard, O., Simonneau, A., Chapron, E., Courp, T., Cerdan, O., Lefèvre, I., Adriaensen, H., Lecompte, F., Desmet, M., 2014. Increase in soil erosion after agricultural intensification: Evidence from a lowland basin in France. Anthropocene, 7: 30-41.

Gaillardet, J., Dupré, B., Allègre, C.J., Negrel, P., 1997. Chemical and physical denudation in the Amazon River Basin. Chemical Geology, 142: 141-173.

Gateuille, D., Evrard, O., Lefevre, I., Moreau-Guigon, E., Alliot, F., Chevreuil, M., Mouchel, J.M., 2014. Mass balance and decontamination times of Polycyclic Aromatic Hydrocarbons in rural nested catchments of an early industrialized region (Seine River basin, France). Science of the Total Environment, 470471: 608-17.

Gay, A., Cerdan, O., Delmas, M., Desmet, M., 2014. Variability of suspended sediment yields within the Loire river basin (France). Journal of Hydrology, 519: 1225-1237.

Gourdin, E., Evrard, O., Huon, S., Lefèvre, I., Ribolzi, O., Reyss, J.-L., Sengtaheuanghoung, O., Ayrault, S., 2014. Suspended sediment dynamics in a Southeast Asian mountainous catchment: Combining river monitoring and fallout radionuclide tracers. Journal of Hydrology, 519: 1811-1823. 
Graustein, W.C., $1989 .{ }^{87} \mathrm{Sr} /{ }^{86} \mathrm{Sr}$ ratios measure the sources and flow of strontium in terrestrial environment. In: Springer, N.-Y. (Ed.), Stable Isotopes in Ecological Research, pp. 491-512.

Grosbois, C., Negrel, P., Fouillac, C., Grimaud, D., 1999. Dissolved load of the Loire River: chemical and isotopic characterization. Chemical Geology, 170(1-4): 179-201.

Haddadchi, A., Olley, J., Pietsch, T., 2015. Variable source contributions to river bed sediments across three size fractions. Hydrological Processes.

Horowitz, A.J., 2008. Determining annual suspended sediment and sediment-associated trace element and nutrient fluxes. Science of the Total Environment, 400(1-3): 315-43.

Jagercikova, M., Cornu, S., Le Bas, C., Evrard, O., 2014. Vertical distributions of ${ }^{137}$ Cs in soils: a meta-analysis. Journal of Soils and Sediments, 15(1): 81-95.

King, K.W., Fausey, N.R., Williams, M.R., 2014. Effect of subsurface drainage on streamflow in an agricultural headwater watershed. Journal of Hydrology, 519: 438-445.

Koiter, A.J., Owens, P.N., Petticrew, E.L., Lobb, D.A., 2013. The behavioural characteristics of sediment properties and their implications for sediment fingerprinting as an approach for identifying sediment sources in river basins. Earth-Science Reviews, 125: 24-42.

Laceby, J.P., Olley, J., Pietsch, T.J., Sheldon, F., Bunn, S.E., 2015. Identifying subsoil sediment sources with carbon and nitrogen stable isotope ratios. Hydrological Processes, 29(8): 1956-1971.

Liu, Y., Métivier, F., Gaillardet, J., Ye, B., Meunier, P., Narteau, C., Lajeunesse, E., Han, T., Malverti, L., 2011. Erosion rates deduced from seasonal mass balance along the upper Urumqi River in Tianshan. Solid Earth, 2(2): 283-301.

Lupker, M., France-Lanord, C., Lavé, J., Bouchez, J., Galy, V., Métivier, F., Gaillardet, J., Lartiges, B., Mugnier, J.L., 2011. A Rouse-based method to integrate the chemical composition of river sediments: Application to the Ganga basin. Journal of Geophysical Research, 116(F4).

Navratil, O., Evrard, O., Esteves, M., Ayrault, S., Lefèvre, I., Legout, C., Reyss, J.-L., Gratiot, N., Némery, J., Mathys, N., Poirel, A., Bonté, P., 2012. Core-derived historical records of suspended sediment origin in a mesoscale mountainous catchment: the River Bléone, French Alps. Journal of Soils and Sediments, 9(1-16).

Négrel, P., Allègre, C.J., Dupré, B., Lewin, E., 1993. Erosion sources determined by inversion of major and trace elment ratios and strontium isotopic ratios in river water: The Congo Basin case. Earth and Planetary Science Letters, 120: 59-76.

Négrel, P., Petelet-Giraud, E., 2004. Strontium isotopes as tracers of groundwater-induced floods: the Somme case study (France). Journal of Hydrology, 305(1-4): 99-119.

Ollivier, P., Radakovitch, O., Hamelin, B., 2011. Major and trace element partition and fluxes in the Rhône River. Chemical Geology, 285(1-4): 15-31.

Owens, P.N., Batalla, R.J., Collins, A.J., Gomez, B., Hicks, D.M., Horowitz, A.J., Kondolf, G.M., Marden, M., Page, M.J., Peacock, D.H., Petticrew, E.L., Salomons, W., Trustrum, N.A., 2005. Fine-grained sediment in river systems: environmental significance and management issues. River Research and Applications, 21(7): 693-717.

Petelet-Giraud, E., Négrel, P., 2007. Geochemical flood deconvolution in a Mediterranean catchment (Hérault, France) by Sr isotopes, major and trace elements. Journal of Hydrology, 337(1-2): 224-241.

Pierson-Wickmann, A.-C., Aquilina, L., Weyer, C., Molénat, J., Lischeid, G., 2009. Acidification processes and soil leaching influenced by agricultural practices revealed by strontium isotopic ratios. Geochimica et Cosmochimica Acta, 73(16): 4688-4704.

Priadi, C., Bourgeault, A., Ayrault, S., Gourlay-France, C., Tusseau-Vuillemin, M.H., Bonte, P., Mouchel, J.M., 2011. Spatio-temporal variability of solid, total dissolved and labile metal: passive vs. discrete sampling evaluation in river metal monitoring. Journal of Environmental Monitoring, 13(5): 1470-9.

Probst, A., El Gh'mari, D., Aubert, D., Fritz, B., McNutt, R., 2000. Strontium as a tracer of weathering processes in a silicate catchment polluted by acid atmospheric inputs, Strengbach, France. Chemical Geology, 170: 203-219.

Rasplus, L., Macaire, J.J., Alcaydé, G., 1982. Carte géologique de Bléré au 1:5000, Editions BRGM. 
Roy, S., Gaillardet, J., Allègre, C.J., 1999. Geochemistry of dissolved and suspended loads of the Seine river, France: Anthropogenic impact, carbonate and silicate weathering. Geochimica et Cosmochimica Acta, 63(9): 1277-1292.

Russell, R., Walling, D.E., Hodgkinson, R.A., 2001. Suspended sediment sources in two small lowland agricultural catchments in the UK. Journal of Hydrology, 252(1-4): 1-24.

Semhi, K., Clauer, N., Probst, J.L., 2000. Strontium isotope compositions of river waters as records of lithology-dependet mass transfers: the Garonne river and its tributaries (SW France). Chemical Geology, 168: 173-193.

Sherriff, S.C., Rowan, J.S., Fenton, O., Jordan, P., Melland, A.R., Mellander, P.-E., hHallacháin, Ó., 2016. Storm Event Suspended Sediment-Discharge Hysteresis and Controls in Agricultural Watersheds: Implications for Watershed Scale Sediment Management. Environmental Science \& Technology, 50(4): 1769-1778.

Smith, H.G., Blake, W.H., 2014. Sediment fingerprinting in agricultural catchments: A critical re-examination of source discrimination and data corrections. Geomorphology, 204: 177-191.

Smith, H.G., Dragovich, D., 2009. Interpreting sediment delivery processes using suspended sedimentdischarge hysteresis patterns from nested upland catchments, south-eastern Australia. Hydrological Processes, 23(17): 2415-2426.

Sogon, S., Penven, M.-J., Bonte, P., Muxart, T., 1999. Estimation of sediment yield and soil loss using suspended sediment load and ${ }^{137} \mathrm{Cs}$ measurements on agricultural land, Brie Plateau, France. Hydrobiologia, 410(251-261).

Vanmaercke, M., Poesen, J., Govers, G., Verstraeten, G., 2015. Quantifying human impacts on catchment sediment yield: A continental approach. Global and Planetary Change, 130: 22-36.

Verstraeten, G., Poesen, J., 1999. The nature of small-scale flooding, muddy floods and retention pond sedimentation in central Belgium. Geomorphology, 29: 275-292.

Viers, J., Dupre, B., Gaillardet, J., 2009. Chemical composition of suspended sediments in World Rivers: New insights from a new database. Science of the Total Environment, 407(2): 853-68.

Walling, D.E., 1977. Assessing the accuracy of suspended sediment rating curves for a small bassin. Water Resource Research, 13: 531-538.

Walling, D.E., Collins, A.L., 2008. The catchment sediment budget as a management tool. Environmental Science \& Policy, 11(2): 136-143.

Walling, D.E., Fang, D., 2003. Recent trends in the suspended sediment loads of the world's rivers. Global and Planetary Change, 39(1-2): 111-126.

Walling, D.E., Owens, P.N., Waterfall, B.D., Graham, J.L., Wass, P.D., 2000. The particle size characteristics of fluvial suspended sediment in the Humber and Tweed catchments, UK. Science of the Total Environment, 251/252: 205-222.

Walling, D.E., Russell, R., Hodgkinson, R.A., Zang, Y., 2002. Establishing sediment budgets for two small lowland agricultural catchments in the UK. Catena, 47: 323-353.

Williams, G.P., 1989. Sediment concentration versus water discharge during single hydrologic events in rivers. Journal of Hydrology, 111(1-4): 89-106.

World Reference Base for Soil Resources, 2006. A framework for international classification, correlation and communication. Food and Agriculture Organization of the United Nations - FAO. IUSS Working Group WRB. World Soil Resources Reports No. 103, Rome, Italy. 


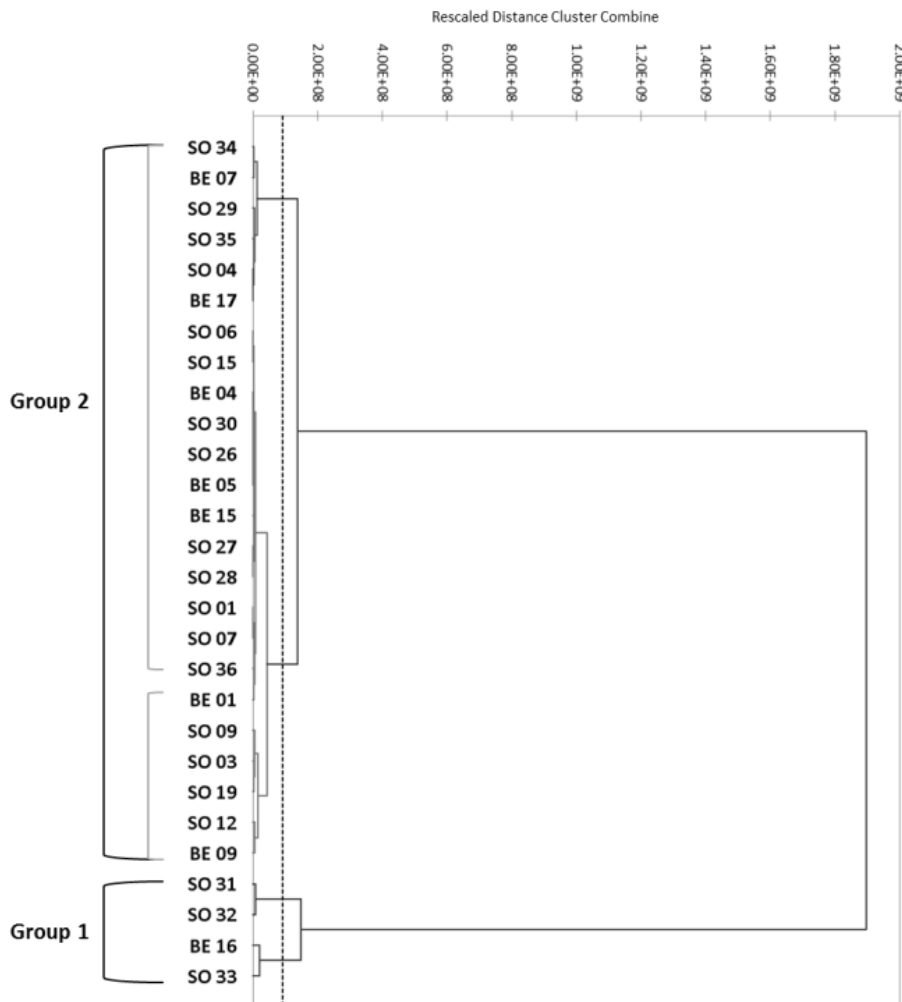

Figure S1. Dendogram of the hierarchical cluster analysis based on ${ }^{87} \mathrm{Sr} /{ }^{86} \mathrm{Sr}$ ratios, $\mathrm{Na}, \mathrm{Mg}, \mathrm{K}, \mathrm{Ca}$, $\mathrm{Rb}$ and $\mathrm{Sr}$ concentration measured in source samples. 
764 Table S1. Summary of ${ }^{87} \mathrm{Sr} /{ }^{86} \mathrm{Sr}$ ratios, element concentrations $\left(\mathrm{mg} \mathrm{kg}^{-1}\right)$ and $1 / \mathrm{Sr}$ and $\mathrm{Rb} / \mathrm{Sr}$ ratios in soil samples.

\begin{tabular}{|c|c|c|c|c|c|c|c|c|c|c|c|c|}
\hline $\begin{array}{c}\text { Sample } \\
\text { ID }\end{array}$ & $\begin{array}{c}\text { Latitude } \\
\left({ }^{\circ} \mathrm{N}\right)\end{array}$ & $\begin{array}{c}\text { Longitude } \\
\left({ }^{\circ} \mathrm{E}\right)\end{array}$ & ${ }^{87} \mathrm{Sr} /{ }^{86} \mathrm{Sr}$ & $\pm 2 \sigma$ & $\begin{array}{c}\mathrm{Na} \\
\left(\mathrm{mg} \mathrm{kg}^{-1}\right)\end{array}$ & $\begin{array}{c}\mathrm{Mg} \\
\left(\mathrm{mg} \mathrm{kg}^{-1}\right)\end{array}$ & $\begin{array}{c}\mathrm{K} \\
\left(\mathrm{mg} \mathrm{kg}^{-1}\right)\end{array}$ & $\begin{array}{c}\mathrm{Ca} \\
\left(\mathrm{mg} \mathrm{kg}^{-1}\right)\end{array}$ & $\begin{array}{c}\mathrm{Rb} \\
\left(\mathrm{mg} \mathrm{kg}^{-1}\right)\end{array}$ & $\begin{array}{c}\mathrm{Sr} \\
\left(\mathrm{mg} \mathrm{kg}^{-1}\right)\end{array}$ & $1 / \mathrm{Sr}$ & $\mathrm{Rb} / \mathrm{Sr}$ \\
\hline SO 01 & 47.151 & 0.76 & 0.722426 & 0.000013 & 3883 & 1184 & 9845 & 2289 & 52 & 50 & 0.020 & 1.04 \\
\hline SO 03 & 47.145 & 0.747 & 0.721704 & 0.000012 & 3259 & 3041 & 12879 & 5577 & 98 & 71 & 0.014 & 1.38 \\
\hline SO 04 & 47.144 & 0.743 & 0.723706 & 0.000005 & 1772 & 795 & 6047 & 1782 & 37 & 29 & 0.034 & 1.26 \\
\hline SO 06 & 47.138 & 0.729 & 0.723199 & 0.000012 & 4226 & 1839 & 12473 & 2725 & 80 & 62 & 0.016 & 1.29 \\
\hline SO 07 & 47.122 & 0.738 & 0.724631 & 0.000008 & 4419 & 1155 & 10681 & 2108 & 62 & 47 & 0.021 & 1.32 \\
\hline SO 09 & 47.13 & 0.757 & 0.719287 & 0.000048 & 2703 & 4004 & 13028 & 7021 & 99 & 74 & 0.013 & 1.33 \\
\hline SO 12 & 47.141 & 0.771 & 0.714943 & 0.000006 & 3403 & 4631 & 9972 & 4002 & 98 & 98 & 0.010 & 1.00 \\
\hline SO 15 & 47.149 & 0.723 & 0.724506 & 0.000006 & 4289 & 1442 & 12125 & 3363 & 43 & 50 & 0.020 & 0.85 \\
\hline SO 19 & 47.158 & 0.739 & 0.721115 & 0.000006 & 2952 & 3059 & 13910 & 4110 & 114 & 73 & 0.014 & 1.56 \\
\hline SO 26 & 47.127 & 0.771 & 0.723899 & 0.000006 & 3075 & 1889 & 11595 & 2012 & 78 & 54 & 0.019 & 1.44 \\
\hline SO 27 & 47.156 & 0.770 & 0.723910 & 0.000006 & 3064 & 1883 & 11555 & 2885 & 68 & 58 & 0.017 & 1.17 \\
\hline SO 28 & 47.138 & 0.723 & 0.721561 & 0.000007 & 3002 & 1845 & 11321 & 3413 & 104 & 66 & 0.015 & 1.58 \\
\hline SO 29 & 47.129 & 0.723 & 0.72388 & 0.000019 & 1352 & 538 & 4103 & 642 & 24 & 19 & 0.054 & 1.28 \\
\hline SO 30 & 47.119 & 0.731 & 0.724116 & 0.000008 & 3360 & 1381 & 11093 & 2267 & 75 & 53 & 0.019 & 1.42 \\
\hline SO 31 & 47.139 & 0.772 & 0.716986 & 0.000006 & 4537 & 4594 & 10253 & 20192 & 94 & 72 & 0.014 & 1.30 \\
\hline SO 32 & 47.138 & 0.758 & 0.712763 & 0.000008 & 1965 & 1997 & 8929 & 20897 & 56 & 152 & 0.007 & 0.37 \\
\hline SO 33 & 47.14 & 0.764 & 0.715012 & 0.000008 & 3056 & 3103 & 8701 & 35698 & 67 & 93 & 0.011 & 0.72 \\
\hline SO 34 & 47.137 & 0.757 & 0.722388 & 0.000008 & 1083 & 1086 & 8092 & 2469 & 50 & 39 & 0.026 & 1.27 \\
\hline SO 35 & 47.135 & 0.753 & 0.717815 & 0.000008 & 1230 & 1242 & 6701 & 2754 & 39 & 51 & 0.020 & 0.76 \\
\hline SO 36 & 47.136 & 0.754 & 0.721163 & 0.000008 & 1860 & 1885 & 10847 & 3404 & 71 & 62 & 0.016 & 1.15 \\
\hline BE 01 & 47.151 & 0.760 & 0.720446 & 0.000049 & 3245 & 2018 & 10077 & 3246 & 66 & 59 & 0.017 & 1.12 \\
\hline BE 04 & 47.138 & 0.729 & 0.722606 & 0.000049 & 3924 & 1935 & 12158 & 1934 & 84 & 63 & 0.016 & 1.33 \\
\hline BE 05 & 47.124 & 0.744 & 0.722340 & 0.000049 & 3393 & 1841 & 11834 & 2473 & 85 & 61 & 0.016 & 1.39 \\
\hline BE 07 & 47.131 & 0.759 & 0.719653 & 0.000008 & 2377 & 1516 & 8809 & 2873 & 58 & 54 & 0.019 & 1.09 \\
\hline BE 09 & 47.141 & 0.771 & 0.720070 & 0.000049 & 3090 & 3937 & 9672 & 6857 & 82 & 53 & 0.019 & 1.56 \\
\hline BE 15 & 47.130 & 0.733 & 0.722685 & 0.000005 & 2820 & 2856 & 12165 & 2692 & 93 & 61 & 0.016 & 1.52 \\
\hline BE 16 & 47.138 & 0.761 & 0.712625 & 0.000006 & 2867 & 2808 & 10527 & 29632 & 74 & 177 & 0.006 & 0.42 \\
\hline BE 17 & 47.154 & 0.740 & 0.721651 & 0.000005 & 1626 & 1352 & 5981 & 1956 & 65 & 48 & 0.021 & 1.34 \\
\hline
\end{tabular}


Table S2. ${ }^{7} \mathrm{Sr} /{ }^{86} \mathrm{Sr}$ ratios, elemental concentrations $\left(\mathrm{mg} \mathrm{kg}^{-1}\right), 1 / \mathrm{Sr}$ and $\mathrm{Rb} / \mathrm{Sr}$ ratios in SPM collected in the rivers (Conteraye, Picarderie, Beaulieu, Masniers, Grand Bray) and at tile drain outlets (Mazère, Brépinnière) during three flood events.

\begin{tabular}{|c|c|c|c|c|c|c|c|c|c|c|c|c|}
\hline $\begin{array}{l}\text { Flood event } \\
\text { Localisation }\end{array}$ & $\begin{array}{c}\text { Suspended } \\
\text { sediment } \\
\text { concentration } \\
(\mathrm{mg} / \mathrm{L}) \\
\end{array}$ & ${ }^{87} \mathrm{Sr} /{ }^{86} \mathrm{Sr}$ & $\pm 2 \sigma$ & $\begin{array}{c}\mathrm{Na} \\
\left(\mathrm{mg} \mathrm{kg}^{-1}\right)\end{array}$ & $\begin{array}{c}\mathrm{Mg} \\
\left(\mathrm{mg} \mathrm{kg}^{-1}\right)\end{array}$ & $\begin{array}{c}\text { Al } \\
\left(\mathrm{mg} \mathrm{kg}^{-1}\right)\end{array}$ & $\begin{array}{c}\mathrm{K} \\
\left(\mathrm{mg} \mathrm{kg}{ }^{-1}\right)\end{array}$ & $\begin{array}{c}\mathrm{Ca} \\
\left(\mathrm{mg} \mathrm{kg}^{-1}\right)\end{array}$ & $\begin{array}{c}\mathrm{Rb} \\
(\mathrm{mg} \mathrm{kg})\end{array}$ & $\begin{array}{c}\mathrm{Sr} \\
\left(\mathrm{mg} \mathrm{kg}^{-1}\right)\end{array}$ & $1 / \mathrm{Sr}$ & $\mathrm{Rb} / \mathrm{Sr}$ \\
\hline \multicolumn{13}{|c|}{ Suspended sediment - $1^{\text {st }}$ flood event $(12 / 30 / 2013)$} \\
\hline Conteraye & 270 & 0.717964 & 0.000012 & 2338 & 5378 & 90028 & 14480 & 6081 & 157 & 78 & 0.013 & 2.01 \\
\hline Picarderie & 335 & 0.718114 & 0.000013 & 1040 & 6760 & 102146 & 14320 & 7055 & 173 & 77 & 0.013 & 2.25 \\
\hline Beaulieu & 414 & 0.718384 & 0.000009 & 900 & 6894 & 102495 & 13085 & 7311 & 178 & 68 & 0.015 & 2.64 \\
\hline Masniers & 337 & 0.715484 & 0.000014 & 1896 & 6379 & 86433 & 14957 & 22546 & 163 & 122 & 0.008 & 1.34 \\
\hline Grand Bray & 386 & 0.716377 & 0.000013 & 1477 & 7293 & 108179 & 17009 & 14457 & 191 & 114 & 0.009 & 1.67 \\
\hline Mazère & 324 & 0.717296 & 0.000014 & 972 & 7582 & 111628 & 15390 & 7445 & 196 & 78 & 0.013 & 2.51 \\
\hline Brépinière & 300 & 0.714202 & 0.000013 & 1095 & 6860 & 101125 & 14511 & 8341 & 166 & 126 & 0.008 & 1.33 \\
\hline \multicolumn{13}{|c|}{ Suspended sediment - $2^{\text {nd }}$ flood event $(01 / 29 / 2014)$} \\
\hline Conteraye & 40 & 0.715734 & 0.000014 & 257 & 5738 & 94320 & 12207 & 12353 & 159 & 97 & 0.010 & 1.64 \\
\hline Picarderie & 167 & 0.718637 & 0.000014 & 624 & 7325 & 117421 & 15557 & 12190 & 193 & 83 & 0.012 & 2.33 \\
\hline Beaulieu & 219 & 0.718188 & 0.000013 & 340 & 7441 & 113307 & 15890 & 11292 & 197 & 86 & 0.012 & 2.29 \\
\hline Masniers & 107 & 0.715671 & 0.000016 & 780 & 6850 & 95783 & 14873 & 7629 & 177 & 113 & 0.009 & 1.56 \\
\hline Grand Bray & 133 & 0.716165 & 0.000014 & 917 & 6723 & 98741 & 15345 & 11385 & 178 & 107 & 0.009 & 1.67 \\
\hline Mazère & 68 & 0.717946 & 0.000013 & n.d & 5911 & 91574 & 11741 & 17278 & 69 & 68 & 0.015 & 1.03 \\
\hline Brépinière & 124 & 0.713660 & 0.000012 & 496 & 6103 & 97440 & 13298 & 12232 & 233 & 121 & 0.008 & 1.93 \\
\hline \multicolumn{13}{|c|}{ Suspended sediment $-3^{\text {rd }}$ flood event $(02 / 13 / 2014)$} \\
\hline Picarderie & 774 & 0.720571 & 0.000011 & 1636 & 3969 & 56006 & 14137 & 7095 & 71 & 62 & 0.016 & 1.15 \\
\hline Beaulieu & 813 & 0.720495 & 0.000012 & n.d & 3529 & 54384 & 13871 & 5425 & 65 & 61 & 0.016 & 1.06 \\
\hline Masniers & 470 & 0.717814 & 0.000012 & 2018 & 6291 & 88825 & 16062 & 11935 & 167 & 90 & 0.011 & 1.86 \\
\hline Grand Bray & 541 & 0.718467 & 0.000012 & 1958 & 5852 & 77427 & 16726 & 9810 & 109 & 80.4 & 0.012 & 1.36 \\
\hline
\end{tabular}

779 
Table S3. ${ }^{87} \mathrm{Sr} /{ }^{86} \mathrm{Sr}$ ratios, $\mathrm{Sr}$ and $\mathrm{Rb}$ concentrations $\left(\mathrm{mg} \mathrm{kg}^{-1}\right)$ in various particle size fractions of the soil samples.

\begin{tabular}{|c|c|c|c|c|}
\hline & Sample ID & ${ }^{87} \mathrm{Sr} /{ }^{86} \mathrm{Sr}$ & $\mathrm{Sr}\left(\mathrm{mg} \mathrm{kg}^{-1}\right)$ & $\mathrm{Rb}\left(\mathrm{mg} \mathrm{kg}^{-1}\right)$ \\
\hline SO 03 & \multirow{3}{*}{ Silicate soils } & 0.721704 & 71 & 98 \\
\hline SO $03<63 \mu \mathrm{m}$ & & 0.722356 & 76 & 99 \\
\hline SO $03<2 \mu \mathrm{m}$ & & 0.719877 & 72 & 151 \\
\hline SO15 & \multirow{3}{*}{ Silicate soils } & 0.724506 & 50 & 43 \\
\hline $\mathrm{SO} 15<63 \mu \mathrm{m}$ & & 0.724667 & 65 & 73 \\
\hline $\mathrm{SO} 15<2 \mu \mathrm{m}$ & & 0.722535 & 58 & 155 \\
\hline SO 19 & \multirow{3}{*}{ Silicate soils } & 0.721115 & 73 & 114 \\
\hline SO $19<63 \mu \mathrm{m}$ & & 0.721521 & 77 & 106 \\
\hline SO $19<2 \mu \mathrm{m}$ & & 0.720018 & 77 & 149 \\
\hline SO 28 & \multirow{3}{*}{ Silicate soils } & 0.721561 & 60 & 104 \\
\hline SO $28<63 \mu \mathrm{m}$ & & 0.722288 & 72 & 95 \\
\hline SO $28<2 \mu \mathrm{m}$ & & 0.720653 & 75 & 159 \\
\hline SO 31 & \multirow{3}{*}{ Carbonate soils } & 0.716986 & 72 & 94 \\
\hline SO $31<63 \mu \mathrm{m}$ & & 0.718687 & 73 & 110 \\
\hline SO $31<2 \mu \mathrm{m}$ & & 0.716922 & 56 & 177 \\
\hline SO 33 & \multirow{3}{*}{ Carbonate soils } & 0.715012 & 93 & 67 \\
\hline SO $33<63 \mu \mathrm{m}$ & & 0.716178 & 101 & 70 \\
\hline SO $33<2 \mu \mathrm{m}$ & & 0.715645 & 81 & 138 \\
\hline SO 35 & \multirow{3}{*}{ Carbonate soils } & 0.717815 & 51 & 39 \\
\hline $\mathrm{SO} 35<63 \mu \mathrm{m}$ & & 0.718855 & 82 & 69 \\
\hline $\mathrm{SO} 35<2 \mu \mathrm{m}$ & & 0.713099 & 120 & 114 \\
\hline SO 36 & \multirow{3}{*}{ Silicate soils } & 0.721163 & 62 & 71 \\
\hline SO $36<63 \mu \mathrm{m}$ & & 0.721510 & 72 & 94 \\
\hline SO $36<2 \mu \mathrm{m}$ & & 0.717482 & 84 & 155 \\
\hline
\end{tabular}

787

788 Table S4. ${ }^{87} \mathrm{Sr} /{ }^{86} \mathrm{Sr}$ ratios, element concentrations $\left(\mathrm{mg} \mathrm{kg}^{-1}\right), 1 / \mathrm{Sr}$ and $\mathrm{Rb} / \mathrm{Sr}$ ratios in the fraction $<63 \mu \mathrm{m}$ of eight soil samples.

\begin{tabular}{|c|c|c|c|c|c|c|c|c|c|c|}
\hline Sample ID & ${ }^{87} \mathrm{Sr} /{ }^{86} \mathrm{Sr}$ & $\pm 2 \sigma$ & $\begin{array}{c}\mathrm{Na} \\
\left(\mathrm{mg} \mathrm{kg}^{-1}\right)\end{array}$ & $\begin{array}{c}\mathrm{Mg} \\
\left(\mathrm{mg} \mathrm{kg}^{-1}\right)\end{array}$ & $\begin{array}{c}K \\
\left(\mathrm{mg} \mathrm{kg}^{-1}\right)\end{array}$ & $\begin{array}{c}\mathrm{Ca} \\
\left(\mathrm{mg} \mathrm{kg}^{-1}\right)\end{array}$ & $\begin{array}{c}\mathrm{Rb} \\
\left(\mathrm{mg} \mathrm{kg}^{-1}\right)\end{array}$ & $\begin{array}{c}\mathrm{Sr} \\
\left(\mathrm{mg} \mathrm{kg}^{-1}\right)\end{array}$ & $\begin{array}{c}1 / \mathrm{Sr} \\
\left(\mathrm{mg} \mathrm{kg}^{-1}\right)\end{array}$ & $\begin{array}{c}\mathrm{Rb} / \mathrm{Sr} \\
\left(\mathrm{mg} \mathrm{kg}^{-1}\right)\end{array}$ \\
\hline SO $03<63 \mu \mathrm{m}$ & 0.722356 & 0.00001 & 3966 & 2951 & 14850 & 5998 & 99 & 76 & 0.013 & 1.30 \\
\hline SO $15<63 \mu \mathrm{m}$ & 0.724667 & 0.00001 & 5233 & 1395 & 14373 & 2791 & 73 & 65 & 0.016 & 1.13 \\
\hline SO $19<63 \mu \mathrm{m}$ & 0.721521 & 0.00001 & 2300 & 2839 & 14741 & 4232 & 108 & 77 & 0.013 & 1.40 \\
\hline SO $28<63 \mu \mathrm{m}$ & 0.722288 & 0.00001 & 3825 & 2403 & 14426 & 3776 & 95 & 72 & 0.014 & 1.32 \\
\hline SO $31<63 \mu \mathrm{m}$ & 0.718687 & 0.00001 & 3804 & 4901 & 13282 & 25472 & 110 & 73 & 0.014 & 1.51 \\
\hline SO $33<63 \mu \mathrm{m}$ & 0.716178 & 0.00000 & 4160 & 3892 & 12255 & 63573 & 70 & 101 & 0.010 & 0.69 \\
\hline SO $35<63 \mu \mathrm{m}$ & 0.718855 & 0.00001 & 5096 & 1893 & 13136 & 4992 & 69 & 82 & 0.012 & 0.85 \\
\hline SO $36<63 \mu \mathrm{m}$ & 0.721510 & 0.00001 & 5056 & 2141 & 14641 & 4266 & 94 & 72 & 0.014 & 1.31 \\
\hline
\end{tabular}

789

790 Table $55 .{ }^{87} \mathrm{Sr} /{ }^{86} \mathrm{Sr}$ ratios, elemental concentrations $\left(\mathrm{mg} \mathrm{kg}^{-1}\right), 1 / \mathrm{Sr}$ and $\mathrm{Rb} / \mathrm{Sr}$ ratios in the clay fraction $(<2 \mu \mathrm{m})$ of eight soil samples.

\begin{tabular}{|c|c|c|c|c|c|c|c|c|c|c|}
\hline Sample ID & ${ }^{87} \mathrm{Sr} /{ }^{86} \mathrm{Sr}$ & $\pm 2 \sigma$ & $\begin{array}{c}\mathrm{Na} \\
\left(\mathrm{mg} \mathrm{kg}^{-1}\right)\end{array}$ & $\begin{array}{c}\mathrm{Mg} \\
\left(\mathrm{mg} \mathrm{kg}^{-1}\right)\end{array}$ & $\begin{array}{c}\mathrm{K} \\
\left(\mathrm{mg} \mathrm{kg}^{-1}\right)\end{array}$ & $\begin{array}{c}\mathrm{Ca} \\
\left(\mathrm{mg} \mathrm{kg}^{-1}\right)\end{array}$ & $\begin{array}{c}R \mathbf{b} \\
\left(\mathrm{mg} \mathrm{kg}^{-1}\right)\end{array}$ & $\begin{array}{c}\mathrm{Sr} \\
\left(\mathrm{mg} \mathrm{kg}^{-1}\right)\end{array}$ & $1 / \mathrm{Sr}$ & $\mathrm{Rb} / \mathrm{Sr}$ \\
\hline SO $03<2 \mu \mathrm{m}$ & 0.719877 & 0.000043 & 49570 & 5460 & 14649 & 7945 & 151 & 72 & 0.014 & 2.10 \\
\hline SO $15<2 \mu \mathrm{m}$ & 0.722535 & 0.000043 & 67941 & 5099 & 14183 & 6859 & 155 & 58 & 0.017 & 2.67 \\
\hline SO $19<2 \mu \mathrm{m}$ & 0.720018 & 0.000043 & 45653 & 4577 & 15164 & 5570 & 148 & 77 & 0.013 & 1.94 \\
\hline SO $28<2 \mu \mathrm{m}$ & 0.720653 & 0.000039 & 39246 & 5044 & 15826 & 5502 & 159 & 75 & 0.013 & 2.12 \\
\hline SO $31<2 \mu \mathrm{m}$ & 0.716922 & 0.000039 & 46947 & 9679 & 13364 & 14842 & 177 & 56 & 0.018 & 3.15 \\
\hline SO $33<2 \mu \mathrm{m}$ & 0.715645 & 0.000039 & 64399 & 6156 & 14752 & 11969 & 138 & 81 & 0.012 & 1.71 \\
\hline SO $35<2 \mu \mathrm{m}$ & 0.713099 & 0.000039 & 56543 & 5423 & 12900 & 10569 & 114 & 120 & 0.008 & 0.94 \\
\hline SO $36<2 \mu \mathrm{m}$ & 0.717482 & 0.000039 & 55603 & 5550 & 14229 & 6487 & 155 & 84 & 0.012 & 1.84 \\
\hline
\end{tabular}


794 Table S6. Relative contributions of the silicate and carbonate end-members to the suspended sediment during three flood events.

\begin{tabular}{|c|c|c|}
\hline Samples & $\begin{array}{c}\text { Carbonate contribution } \\
(\%)\end{array}$ & $\begin{array}{c}\text { Silicate contribution } \\
(\%)\end{array}$ \\
\hline \multicolumn{3}{|c|}{$1^{\text {st }}$ flood event ( $<2 \mu \mathrm{m}$ fraction) } \\
\hline Grand Bray (GB1) & 73 & 27 \\
\hline Masniers (MS1) & 94 & 6 \\
\hline Brépinière (BR1) & 100 & 0 \\
\hline Conteraye (CO1) & 40 & 60 \\
\hline Beaulieu (BE1) & 32 & 68 \\
\hline Picarderie (PI1) & 37 & 63 \\
\hline Mazère (MZ1) & 54 & 46 \\
\hline \multicolumn{3}{|c|}{$2^{\text {nd }}$ flood event ( $<2 \mu \mathrm{m}$ fraction) } \\
\hline Grand Bray (GB2) & 78 & 22 \\
\hline Masniers (MS2) & 89 & 11 \\
\hline Brépinière (BR2) & 100 & 0 \\
\hline Conteraye (CO2) & 88 & 12 \\
\hline Beaulieu (BE2) & 36 & 64 \\
\hline Picarderie (PI2) & 27 & 73 \\
\hline Mazère (MZ2) & 40 & 60 \\
\hline \multicolumn{3}{|c|}{$3^{r d}$ flood event (<2 mm fraction) } \\
\hline Grand Bray (GB3) & 36 & 64 \\
\hline Masniers (MS3) & 45 & 55 \\
\hline Beaulieu (BE3) & 15 & 85 \\
\hline Picarderie (PI3) & 14 & 86 \\
\hline
\end{tabular}

795 